\title{
The Species Richness of Vascular Plants and Amphibia in Major Plant Communities in Temperate to Tropical Australia: Relationship with Annual Biomass Production
}

\author{
R. L. Specht ${ }^{1}$ and M. J. Tyler ${ }^{2}$ \\ ${ }^{1}$ Botany Departments, Universities of Adelaide, Melbourne, and Queensland, 107 Central Avenue, Saint Lucia, \\ Queensland 4067, Australia \\ ${ }^{2}$ Department of Environmental Biology, University of Adelaide, South Australia 5005, Australia
}

Correspondence should be addressed to R. L. Specht, r.specht@uqconnect.net

Received 6 November 2009; Accepted 9 May 2010

Academic Editor: Mark S. Ashton

Copyright ( $) 2010$ R. L. Specht and M. J. Tyler. This is an open access article distributed under the Creative Commons Attribution License, which permits unrestricted use, distribution, and reproduction in any medium, provided the original work is properly cited.

\begin{abstract}
Aerodynamic fluxes (frictional, thermal, evaporative) in the atmosphere as it flows over and through a plant community determine the Foliage Projective Covers and eco-morphological attributes of new leaves developed annually in overstorey and understorey strata. The number of leaves produced on vertical foliage shoots depends on available soil water and nutrients, also ambient temperature, during this short growth season. Stem density (number of stems per hectare) and species richness (number of species per hectare) in the overstorey of major Floristic Groups are correlated with annual shoot growth (ASG, $t \mathrm{ha}^{-1}$ ) in that stratum. Species richness in the overstorey increases in the climatic gradient from the arid to the humid zone as well as with increasing air temperatures (about $10^{\circ} \mathrm{C}$ ) from temperate to tropical Australia. Species richness in the understorey is highest in plant communities in temperate Australia, decreasing in the temperature gradient towards the tropics. As with other major plant and animal groups within an ecosystem, the species richness of Amphibia is correlated with the amount of solar energy fixed (per annum) by the major plant formation in the region-a photosynthetic potential determined by the foliage shoots (ASG, $t$ ha ${ }^{-1}$ ) produced annually in the overstorey.
\end{abstract}

\section{Introduction}

Over the last 60 years, the first author has pioneered the study of community-physiology (known as crop-physiology in agriculture) - the physicochemical processes that determine the structure, growth, and biodiversity in evergreen plant communities (with associated consumers and decomposers) from the tropical north to the temperate south of Australia.

The discipline of community-physiology was promoted by the International Biological Program (IBP) as part of Section PP Physiological Processes in Terrestrial Ecosystems [1].

The structures of plant formations-closed-forest, tall open-forest, open-forest, woodland, low woodland, tall shrubland, low shrubland-that are found from the perhumid to the arid climatic zones from the tropical north to the temperate south of the Australian continent are essentially similar [2].

The Foliage Projective Cover (FPC) of the overstorey (FPCo $>2 \mathrm{~m}$ ) and understorey ( $\mathrm{FPCu}<2 \mathrm{~m}$ ) strata of terrestrial evergreen plant communities had to be precisely measured using upward and downward crosswire sighting tubes at every $50 \mathrm{~cm}$ along six randomly located line transects [3]. The combined sum of (FPCo + FPCu) has been found to be essentially constant throughout the life cycle of a "climax" plant community both in post-fire successions and in plant communities along both edaphic and wetland continua [4-7]. 
The Foliage Projective Covers of the overstorey and understorey strata-the horizontal spread of each plant that forms the plant formation-are determined during the short growing season of each plant within the plant community. Aerodynamic fluxes (frictional, thermal, evaporative) "abrade" the edges of each plant as the atmosphere flows over and through the plant community.

During the same short period of foliage growth, aerodynamic fluxes determine the ecomorphological development of all new leaves on vertical shoots-Leaf Area (LA, mean area of a mature leaf) and Leaf Specific Weight (LSW, dry weight per unit leaf area, a measure of the proportion of structural to cytoplasmic components of the leaf).

The number of leaves produced on each foliage shoot, however, depends on the transport of available soil nutrients and soil water in the transpiration stream during this short period of foliage growth $[8,9]$. The total leaf area (per hectare) of each stratum is termed the Leaf Area Index (LAI) of the plant community.

During this short period of vertical foliage growth, essentially the same number of mature leaves from the previous year is abscissed as they are formed in the current year (demonstrated on tagged shoots by [10-15]). Hence, the dry weight of the new foliage leaves produced per hectare can be assessed in randomly located litter trays, measured throughout the year. The Annual Shoot Growth (ASG, the dry weight per hectare of foliage leaves produced annually in the overstorey) has been estimated for evergreen plant communities from the tropical north to the temperate south of Australia on soils of medium-nutritional status [11, 12].

Although the number of leaves shed from vertical foliage shoots during the short period of foliage growth is essentially the same as the number produced, often one of the leaves that were produced during the previous year is retained on the vertical foliage shoot. An approximate estimate of the Leaf Area Index (LAI, total leaf area per hectare) of the overstorey can be calculated by increasing the area of the leaves in the litter by $20 \%$. This Leaf Area Index of the overstorey provides an estimate of all the leaves per hectare that intercept solar radiation energy for photosynthesis throughout the year.

The species richness (the number of plant species per hectare) of overstorey and understorey strata in plant communities, from temperate to tropical Australia, from the arid to the perhumid climatic zone, has been shown to be correlated with the Annual Shoot Growth (ASG, dry weight per hectare) of foliage shoots in the overstorey $[11,12,14-$ $16,18]$.

The species richness of small mammals trapped in a range of plant communities across tropical Australia was closely correlated with the number of plant species that composed the overstorey and understorey strata of these 13 plant communities [21]. A similar relationship between small mammals and plant species was demonstrated in seven sampling sites in southern Australia (coordinated by Catling [22]; summarized by Specht [23, page 154]). The species richness of small mammals in southern Australia, however, showed a steeper linear correlation between the species richness of small mammals and the plant species recorded in the combined overstorey and understorey of the seven plant communities (see [16, Figure 17.14a]). The differences in slope of the linear regressions in tropical and temperate Australia were integrated into one linear regression when the species richness of small mammals was plotted against the species richness of the plants recorded in only the understorey stratum [16, Figure 17.14b].

A similar statistical relationship was observed between the number of species of resident birds and the number of plant species-mostly overstorey species-recorded in remnant stands of subtropical rainforests in north-eastern New South Wales [16, 24, Figure 17.1].

The species richness of vertebrates (amphibia, lizards, mammals, birds, but not elapid snakes), also plant species, recorded in plant communities - from the arid to the humid climatic zones - in south-western Australia is consistently lower than recorded in plant communities in south-eastern Australia (see $[16,17]$ —summarized in Figure 1). The infertility of the ancient soils of Western Australia [20, 25], when compared with the relatively recent soils in eastern Australia, appears to have contributed to reduced species richness (per plant community) within south-western ecosystems (Figure 2).

In this paper, the relationship of species richness of overstorey and understorey plants in major plant communities, and Amphibia in associated wetlands, is explored (1) along the climatic gradient from the arid to the humid zones in temperate, subtropical, and tropical Australia and (2) in the edaphic gradient from extremely nutrient-poor to nutrientrich soils.

\section{Methods}

2.1. Evaporative Coefficients of Each Sampling Locality. The community-physiological constant-the evaporative coefficient $(k)$ _of each sampling locality was computed by optimising the monthly rate of usage of soil water so that some water (albeit minimal) is available for evapotranspiration from the evergreen plant community even during the driest season of the year (See (1), after Specht [26]). The perhumid climatic zone is defined, where $k>0.75 \times 10^{-2}$; humid climatic zone- $k=0.75-0.55 \times 10^{-2}$; subhumid climatic zone- $k=0.55-0.45 \times 10^{-2}$; semiarid climatic zone$k=0.45-0.35 \times 10^{-2} ;$ arid climatic zone- $k<0.35 \times 10^{-2}$ (All $k$ values per mm of soil water available per month).

For every macroclimate, in spite of seasonal and yearly fluctuations in rainfall, the monthly moisture index (M.I.), the ratio of actual to potential evapotranspiration $\left(E_{a} / E_{p}\right)$, is correlated to available water $(W \mathrm{~mm})$ by the evaporative coefficient $(k)$ [26-28]—defined by analysis of long-term soil moisture studies of representative plant communities from the arid to the humid climatic zone [29-34] as

$$
\text { M.I. }=\left(\frac{E_{a}}{E_{p}}\right) \cdot\left(\frac{E_{a}}{E_{o}}\right)=k W=k\left(P-R-D-S_{\text {ext }}\right) \text {, }
$$

where $k$ is evaporative coefficient (a community-physiology constant), Ea is actual evapotranspiration ( $\mathrm{mm}), E p$ is potential evapotranspiration $(\mathrm{mm}), E_{o}$ is pan evaporation $(\mathrm{mm})$, which was estimated using mean maximum temperature and 

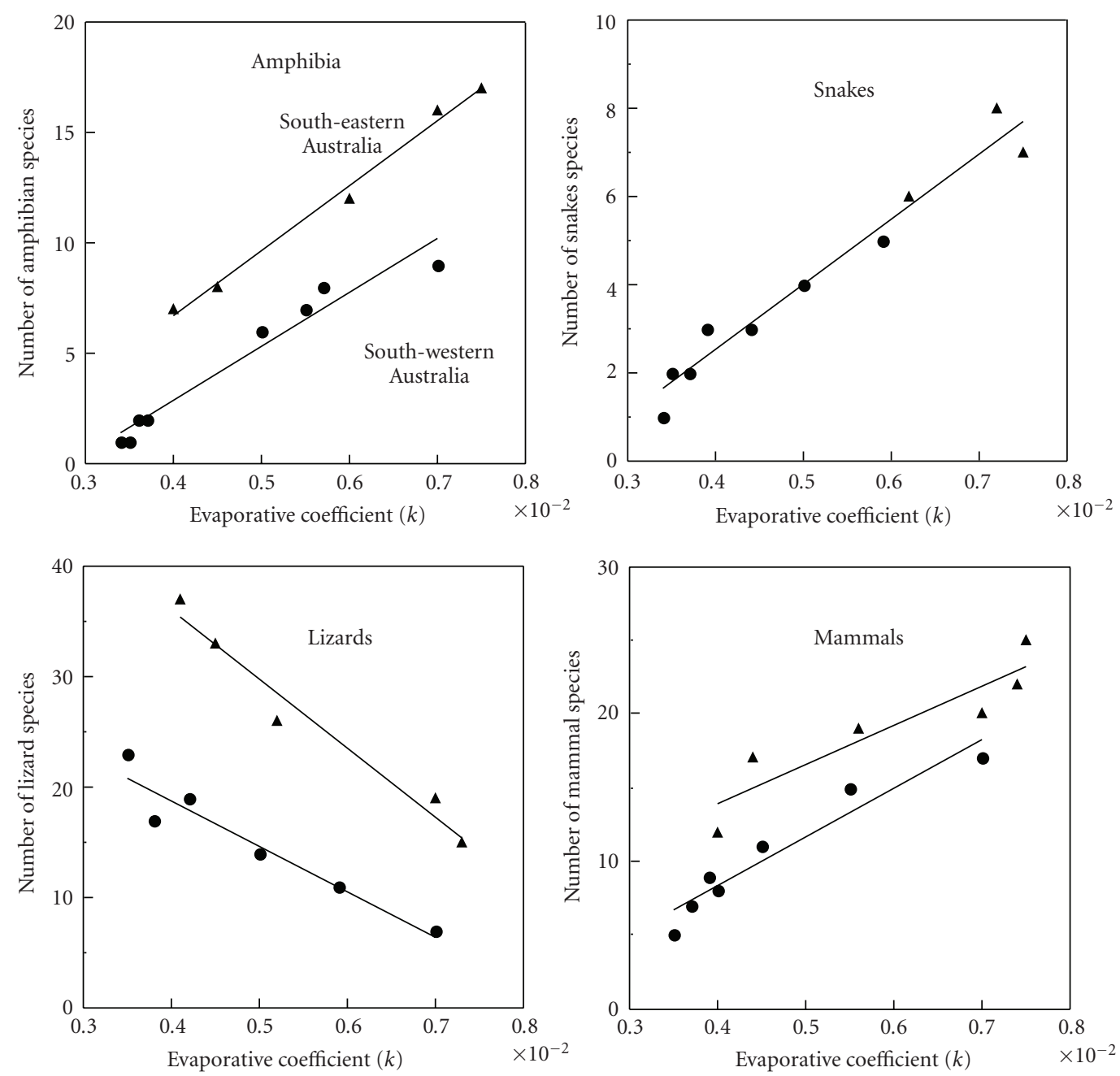

(a)

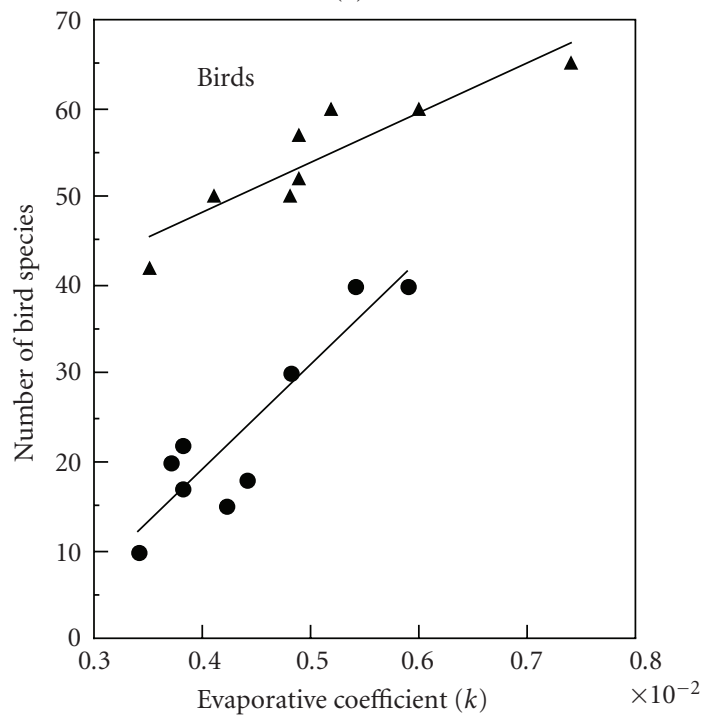

(b)

Figure 1: (a) Alpha diversity of amphibians, elapid snakes, lizards, and small mammals resident in plant communities in south-western (o) and south-eastern Australia $(\triangle)$, plotted along the climatic gradient from the semiarid (Evaporative Coefficient, $k=0.35-0.45 \times 10^{-2}$ ) to the humid $\left(k=0.55-0.75 \times 10^{-2}\right)$ climatic zones (after $\left.[15,16]\right)$. (b) Alpha diversity of birds resident in plant communities in south-western (o) and south-eastern Australia $(\triangle)$, plotted along the climatic gradient from the semiarid (Evaporative Coefficient, $k=0.35-0.45 \times 10^{-2}$ ) to the humid $\left(k=0.55-0.75 \times 10^{-2}\right)$ climatic zones (after $\left.[15,16]\right)$. (Data for south-western Australia are summarized by Specht in [17] and revised by Professor Martin Cody, UCLA). 


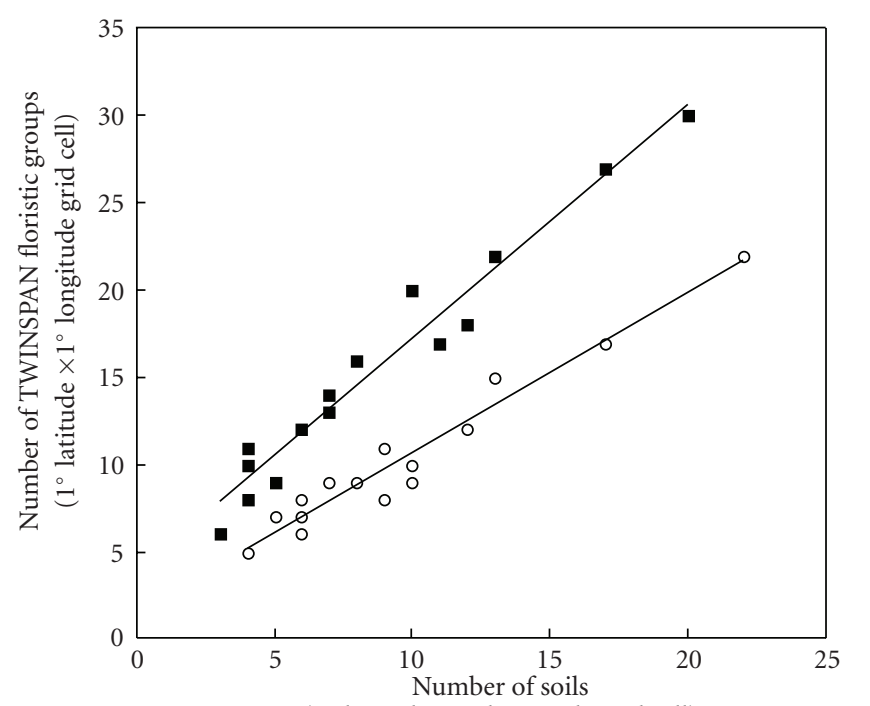

$\left(1^{\circ}\right.$ latitude $\times 1^{\circ}$ longitude grid cell $)$

घ Eastern and southern Australia

- Northern and south-west western Australia

Figure 2: Number of TWINSPAN Floristic Groups (per $1^{\circ}$ latitude $\times 1^{\circ}$ longitude grid cell), plotted against the number of Soil Groups recorded in the same grid cells in south-eastern and Western Australia $[19,20]$. South-eastern Australia Floristic Groups $=1.34$ Soil Groups + $3.83\left(n=15 ; r^{2}=0.96\right)$. Western Australia Floristic Groups $=0.92$ Soil Groups $+1.51\left(n=15 ; r^{2}=0.95\right)$.

vapour pressure [35], $P$ is monthly precipitation $(\mathrm{mm}), R$ is monthly runoff $(\mathrm{mm}), D$ is monthly drainage $(\mathrm{mm})$, and $S_{\text {ext }}$ is extractable soil water ( $\mathrm{mm}$ at the beginning of the month) (between Permanent Wilting Percentage and Field Capacity).

2.2. Primary Productivity of Plant Formations in Equilibrium with the Macroclimate. Aerodynamic forces (frictional, thermal, evaporative) in the atmosphere as it flows over and through a plant community determine foliage coverage (FPC) and leaf attributes (Leaf Area (LA), Leaf Specific Weight (LSW)) during the annual phenophase of shoot growth. The annual biomass production (per hectare) of new leaves can be estimated by measuring (1) the number and biomass of leaves produced annually on tagged shoots and (2) the number and biomass of leaves collected throughout the year in litter traps [10]. These estimates of the annual production of foliage shoots (ASG, $\mathrm{t} \mathrm{ha}^{-1}$ ) have been collated for the overstorey stratum in "climax" plant formations on medium-nutrient soils in the climatic gradient from the arid to the perhumid zone in temperate, subtropical and tropical regions of eastern Australia $[11,12,14]$ as shown in the following equation.

$$
\text { In tropical Australia, ASG }=13.76(100 * \mathrm{k})^{1.249} .
$$

In subtropical Australia, ASG $=11.10(100 * \mathrm{k})^{1.283}$.

In temperate Australia, ASG $=8.08(100 * \mathrm{k})^{1.425}$.
The Evaporative Coefficient $(k)$ of each sampling locality thus enables an estimate of the annual growth of foliage shoots in the overstorey stratum to be computed-for plant communities on medium-nutrient soils.

2.3. Primary Productivity of Plant Communities along Soil Nutritional Gradients. An assessment of the influence of soil fertility on biomass production of plant communities was made (1) in nutritional experiments conducted in the field $[36,38]$ and (2) in glasshouse experiments conducted on the relative growth of eucalypts dominant on soils with a fertility range from extremely nutrient poor to nutrient richdifferentiated by foliar nutrient (particularly phosphorus and nitrogen) levels in overstorey leaves [16].

Relative to the annual foliage growth (ASG, $\mathrm{t} \mathrm{ha}^{-1}$ ) in "climax" plant communities on medium-nutrient soils (Figure 3(a)), annual shoot growth (dry weight measured in $\mathrm{t} \mathrm{ha}^{-1}$ ) in major plant formations on nutrient-poor soils is about $60 \%$ less, $50 \%$ less on extremely nutrient-poor soils, and $130 \%$ more on nutrient-rich soils (Figure 3(a), after $[16,36])$.

Details of the nutrient status of the soils associated with each Floristic Group at each collecting locality were collated from soil and vegetation surveys of Australia [16, 20, 25, 39]. These data on soil nutrient status enabled an assessment of the relative primary production of foliage shoots (ASG, $t$ $\mathrm{ha}^{-1}$ ) at each sampling site (Table 1).

2.4. Species Richness of Vascular Plants (per Hectare). The species richness of vascular plants in any plant community may be assessed by the asymptote of the species-area curve [94], where the number of species is recorded in random quadrats of increasing area from zero to at least one hectare-essentially the area of vegetation assessed in the releve phytoécologue in the survey of the vegetation around the Mediterranean Basin $[95,96]$ and in the survey of the land systems in northern Australia [97, 98].

The floristic composition of plant communities has been recorded by plant ecologists in relevés in every $30^{\prime}$ latitude $\times 30^{\prime}$ longitude grid cell throughout Australia. These lists have been collated in eight large data banks and analysed objectively by the classificatory program TWINSPAN [99] into Floristic Groups [39].

The numbers of vascular plants that have been recorded in the overstorey and understorey strata in the "climax" Floristic Group representative of each amphibian sampling area in southern and northern Australia are tabulated in Table 1.

As the number of months when the rooting zone is waterlogged increases along a wetland continuum, the species richness of the plant communities shows a continuous decline from the "climax" plant community [7]. The sum of overstorey and understorey Foliage Projective Covers (FPCo $+\mathrm{FPCu}$ ), however, remains relatively constant along the wetland continuum [7].

2.5. Species Richness of Amphibia (per Major Plant Community). In the 1980s, the International Society for Mediterranean Ecosystems endeavoured to collate the species 


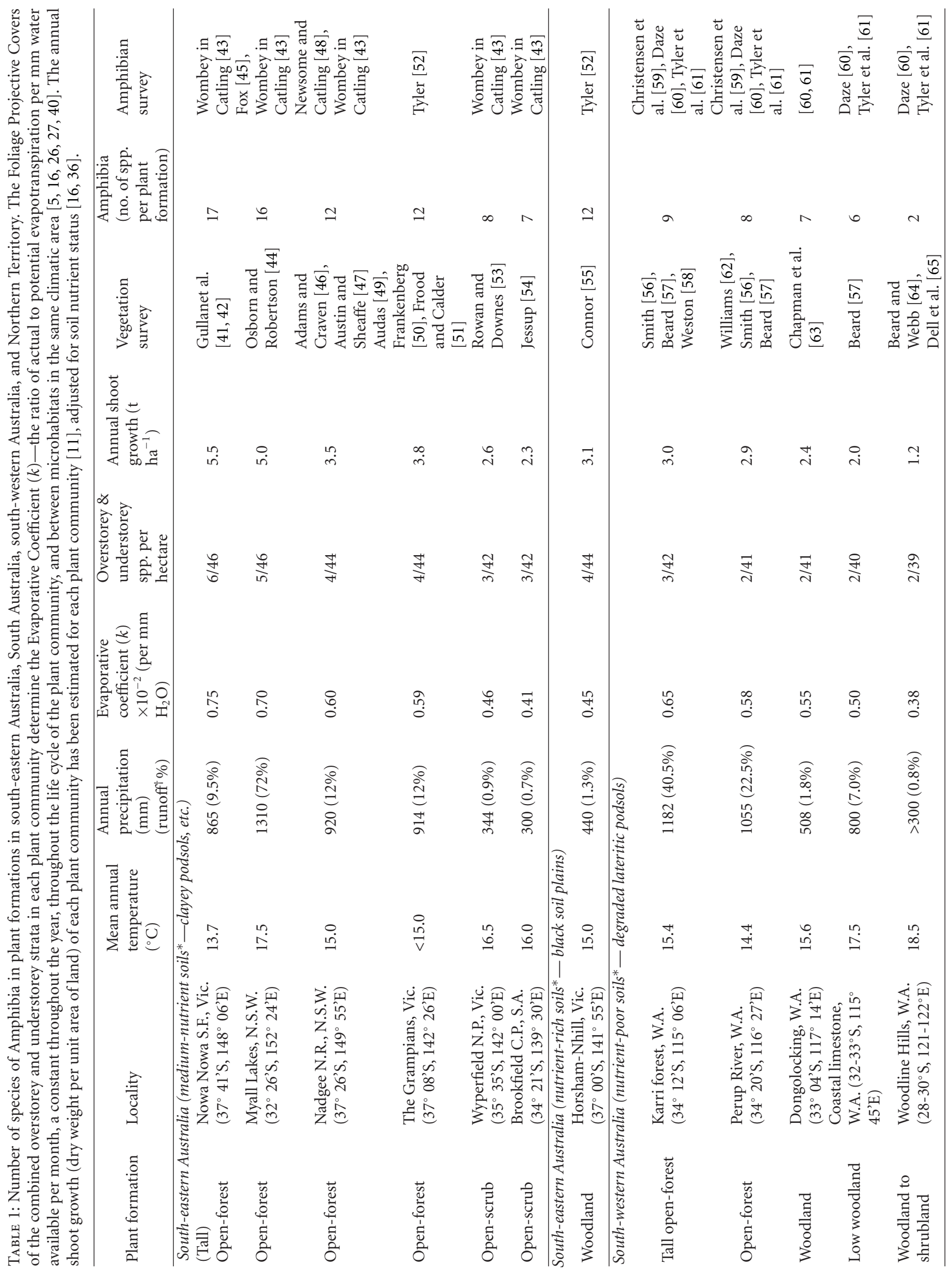




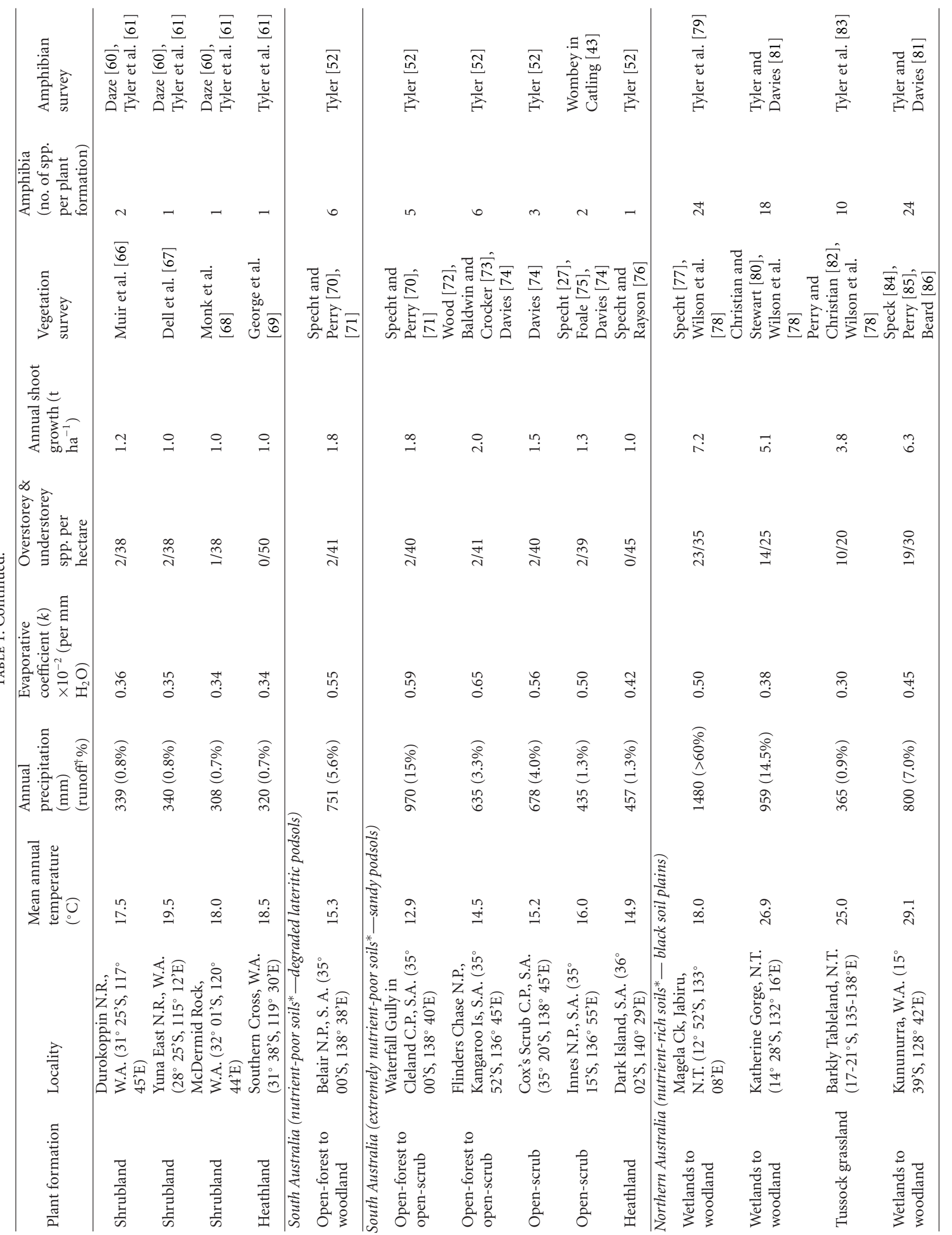




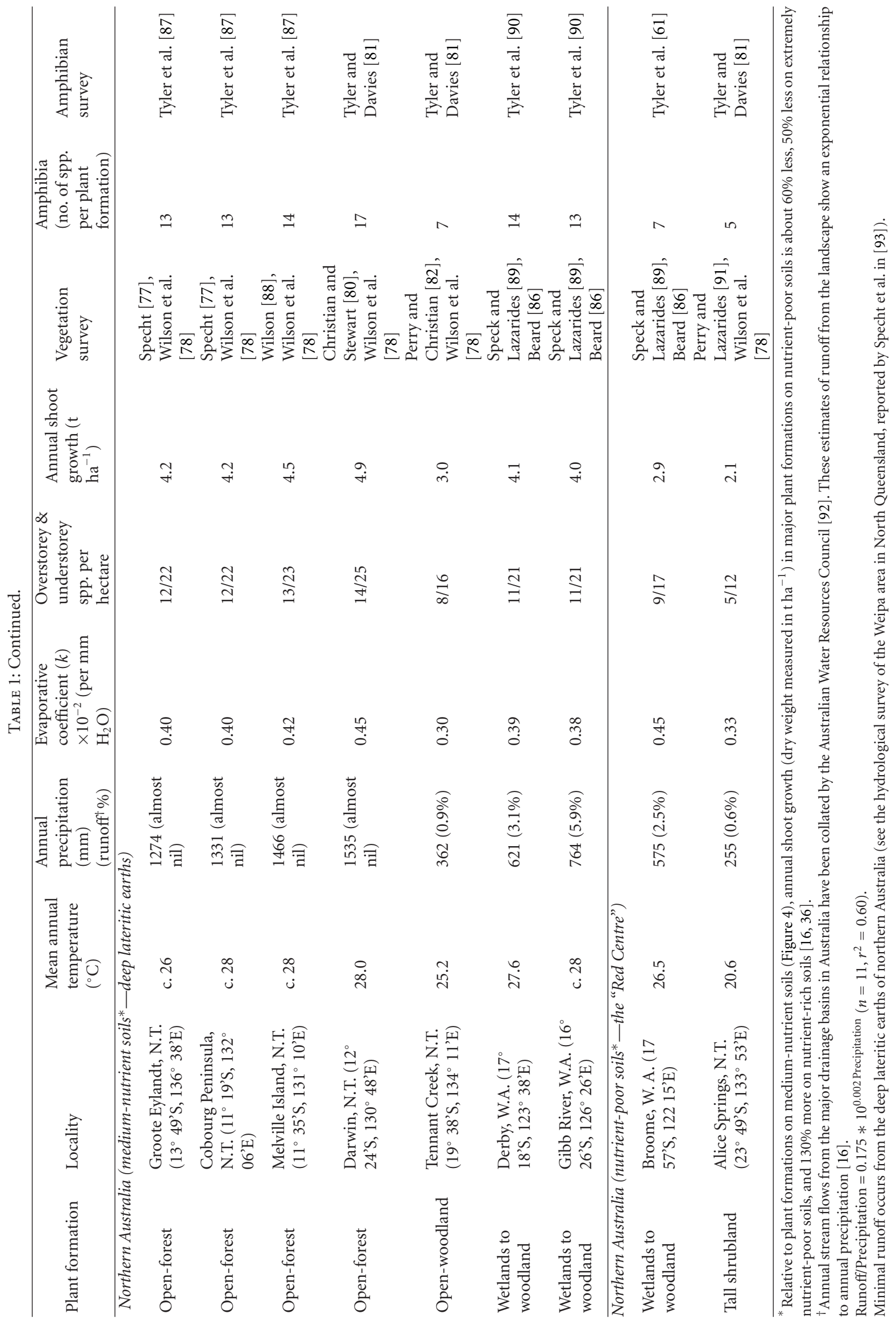




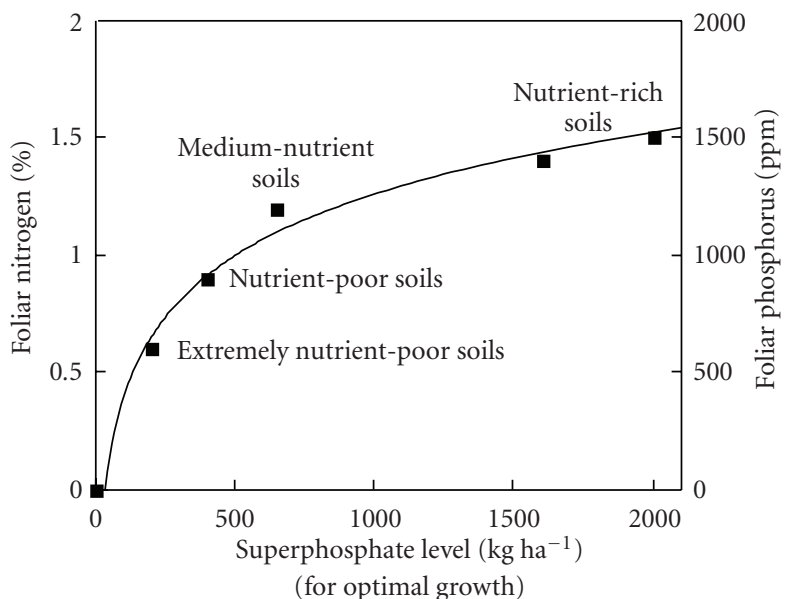

(a)

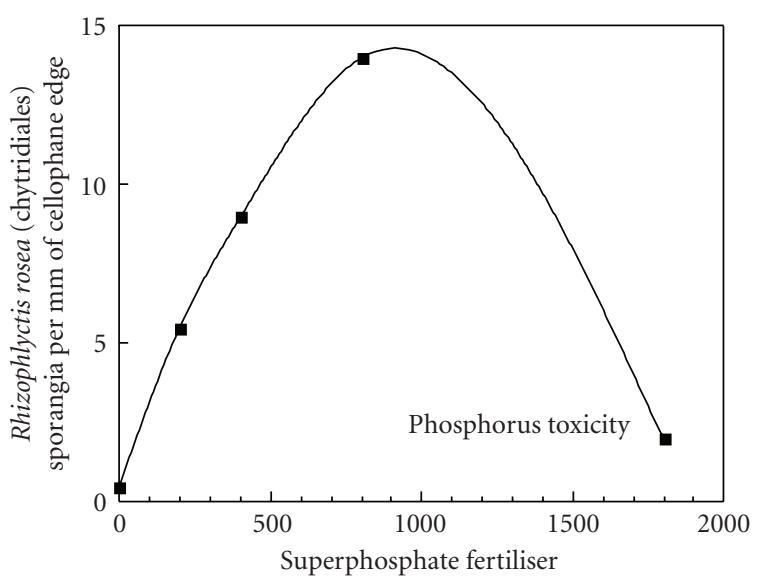

$\left(\mathrm{kg} \mathrm{ha}^{-1}\right)$

(b)

FIGURE 3: (a) Both foliar phosphorus and foliar nitrogen levels in overstorey leaves increase to an asymptote in the soil nutrient gradient from extremely nutrient-poor to nutrient-poor to medium-nutrient to nutrient-rich habitats (after [16]). Foliar $N=0.877 \mathrm{LOG}$ (Super-PO 4 optimum) $-1.374\left(n=6, r^{2}=0.97\right)$. Relative to plant formations on medium-nutrient soils, annual shoot growth (dry weight measured in $\mathrm{t} \mathrm{ha}^{-1}$ ) in major plant formations on nutrient-poor soils is about $60 \%$ less, $50 \%$ less on extremely nutrient-poor soils, and $130 \%$ more on nutrient-rich soils $[16,36]$. (b) Response of the chytrid fungal species, Rhizophlyctis rosea, to the addition of superphosphate $\left(\mathrm{kg}^{-1} \mathrm{~h}^{-1}\right)$ to fertilized plots of heathland vegetation at Frankston, Victoria (after [37]).

richness (the number of species of plants and vertebrates) in major plant communities in the Mediterranean-climate regions of the world-Mediterranean Basin, California and Arizona in the United States, Chile, Cape Province in South Africa, and southern Australia. These statistics of species richness of plants and vertebrates (also of invertebrates) in representative ecosystems, in the climatic gradient from the humid to the arid zone, were published in the study in [100]. In this compilation, the numbers of species of mammals, birds, reptiles, and Amphibia were collated [22]. The statistics on the number of species of Amphibia in six major plant communities in south-eastern Australia and eight major plant communities in south-western Australia were tabulated by Catling and coworkers in [22]. Further statistics on the species richness of Amphibia were supplied by Tyler for Victoria (two localities), South Australia (four localities), Northern Territory (nine localities), and the Kimberleys of Western Australia (four localities).

\section{Results}

3.1. Evaporative Coefficients $(k)$ of Sampling Sites. The evaporative coefficients computed for monsoonal northern Australia (Table 1) indicate that the sampling regions range in climate from the subhumid $\left(k=0.55-0.45 \times 10^{-2}\right)$ to the semiarid zone $\left(k=0.45-0.35 \times 10^{-2}\right)$.

In contrast, the evaporative coefficients computed for temperate southern Australia (Table 1) indicate that the sampling regions range in climate from the humid $(k=$ $\left.0.75-0.55 \times 10^{-2}\right)$ to the semiarid zone $(k=0.45-0.35 \times$ $\left.10^{-2}\right)$.

3.2. Annual Foliage Shoot Growth (ASG, $t h a^{-1}$ ) in Overstorey Strata. Solar energy fixation by photosynthesis in the leaves of both overstorey and understorey plants within a plant community is influenced by the horizontal (FPC) and vertical (LAI) distribution of foliage, ambient temperature, and high-energy phosphorus and nitrogen compounds in the mature leaves [9]. So far, it has been only possible to assess the annual biomass production of new foliage leaves per hectare of plant communities-from the temperate south to the tropical north on medium-nutrient soils in eastern Australia (Equations (2)-(4)). This nutrient classdefined by Kulczynski Symmetric analyses of the major foliar nutrients in overstorey and understorey leaves [16]is characteristic of the clayey podsolic soils in temperate Australia and the deep lateritic earths in monsoonal Australia (Table 1).

The responses of a range of eucalypt and heath species to the application of phosphate to soils (in the glasshouse and in the field) have been assessed (Figure 3(a)). The nutrientpoor lateritic soils characteristic of much of south-western Australia reduce the annual growth of foliage shoots (per hectare) by roughly 60\%; extremely nutrient-poor sandy soils show a reduction of about $50 \%$. The fertility of the nutrient-rich black soils of the coastal plains of northern Australia and in the inland cracking clays of the Barkly Tableland, the Darling Downs, as well as the Riverina and the Wimmera-Tatiara Districts increases annual growth by $120 \%-130 \%$ above that of the medium-nutrient soils. Adjusted values of the annual growth of foliage shoots (ASG, $\mathrm{t} \mathrm{ha}^{-1}$ ) are tabulated in Table 1.

3.3. Species Richness of Vascular Plants and Annual Foliage Shoot Growth. The species richness (number of species per hectare) of vascular plants in the overstorey stratum of major plant communities growing on medium-nutrient soils in the arid to the humid climatic zones of tropical, subtropical, 


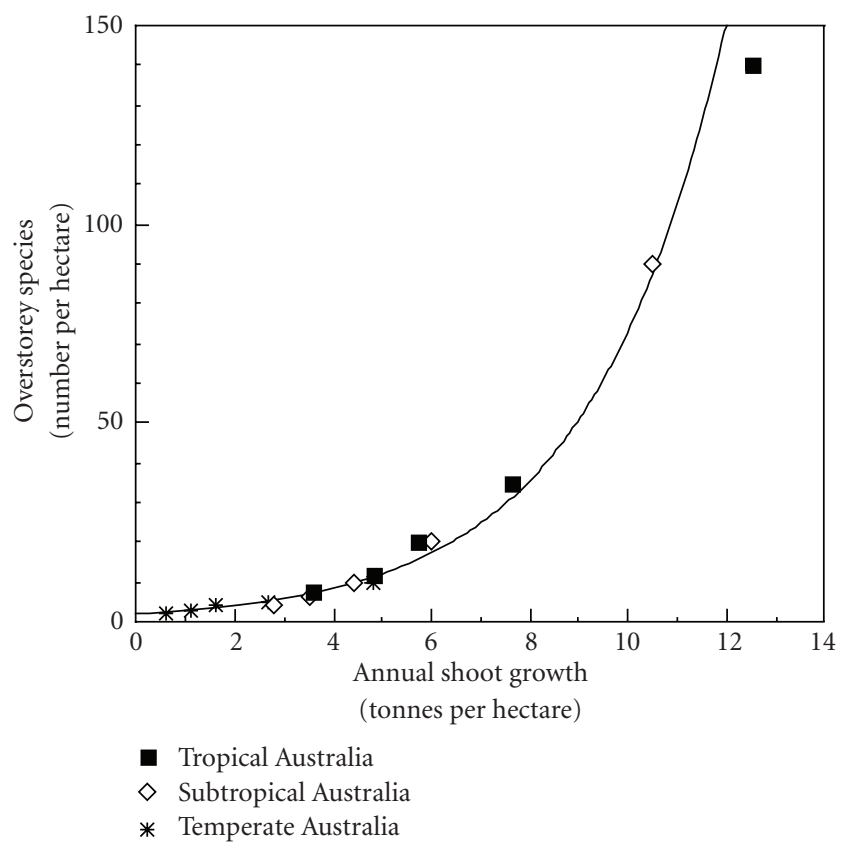

(a)

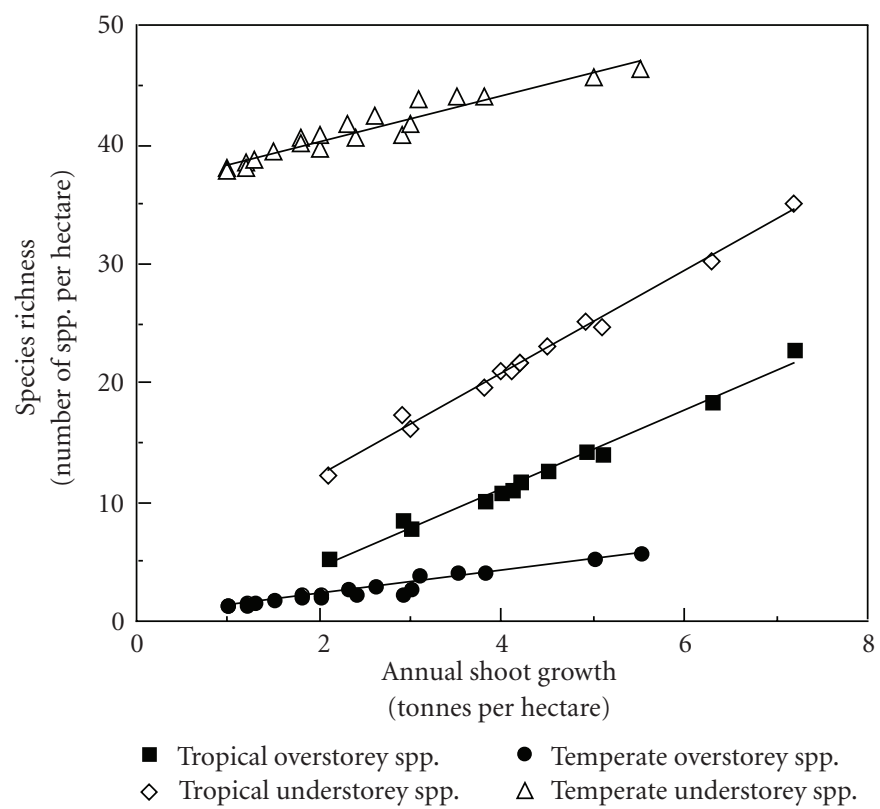

(b)

Figure 4: (a) The relationship between species richness ( $N$, number of species per hectare) of overstorey species in major plant communities-growing on soils of medium nutrient status-with Annual Shoot Growth (biomass per hectare) in tropical, subtropical and temperate eastern Australia (after $[14,15])$. Overstorey $N=1.95 * 10^{0.157 \text { ASG }}\left(n=15 ; r^{2}=0.98\right)$. (b) The relationship between species richness $(N$, number of species per hectare) of overstorey and understorey species in major plant communities-growing on nutrient-rich to nutrient-poor soils - with Annual Shoot Growth (ASG, biomass per hectare) in tropical and temperate Australia (Table 1). Temperate overstorey $N=0.99$ ASG $+0.35\left(n=20 ; r^{2}=0.94\right)$. Temperate understorey $N=1.93$ ASG $+36.5\left(n=20 ; r^{2}=0.93\right)$. Tropical overstorey $N$ $=3.33$ ASG $-2.13\left(n=13 ; r^{2}=0.98\right)$. Tropical understorey $N=4.30$ ASG $+3.61\left(n=13 ; r^{2}=0.99\right)$.

and temperate eastern Australia is related exponentially to annual shoot growth (ASG, $\mathrm{tha}^{-1}$ ) in the overstorey stratum (Figure 4(a), after [16]).

As all the sampling sites in tropical northern Australia lie within the subhumid to semiarid climatic zone, the species richness data assembled in Table 1 fall on the essentially linear part, near the origin, of the exponential curve (Figure 4(a)). This linear relationship between species richness of vascular plants and annual shoot growth is shown in Figure 4(b).

Even though the sampling sites in temperate Australia extend from the semiarid to the wetter humid climatic zone, these data are located on the linear part, near the origin, of the exponential curve (Figures 4(a) and 4(b)).

3.4. Species Richness of Vascular Plants and Amphibia. The species richness of vascular plants in the overstorey and understorey strata of major Floristic Groups-also the Amphibia in wetlands associated with these Floristic Groups - is tabulated in Table 1. Even though the climate of most of the Top End of the Northern Territory is largely subhumid (and only rarely in the humid zone), the species richness of the overstorey strata reaches 23 species per hectare, markedly in contrast to the species richness (six per hectare) of the overstorey in the humid climatic zone of temperate Australia. The species richness of the understorey, however, is lower in the monsoonal north (12 to a maximum of 35 species per hectare) in comparison to that in temperate Australia (39-46 species per hectare). The number of amphibian species recorded (Table 1) in temperate Australia (one to 17 species) is less than the numbers recorded in the monsoonal north (five to 24 species).

The number of amphibian species is strongly correlated with the number of species of vascular plants-overstorey and understorey strata-in the major Floristic Group of each region (Figure 5).

\subsection{Species Richness of Amphibia and Annual Foliage Shoot} Growth. Species richness (per region) of Amphibia declines continuously in the macroclimatic gradient from the humid to the semiarid zone in south-eastern Australia, southwestern Australia, and the wet-dry tropics of northern Australia (Figure 6(a)). On the medium-rich soils of southeastern Australia, species richness of Amphibia is higher, by three to five species, than that of species recorded on the nutrient-poor lateritic soils of south-western Australia. Species richness is further reduced on the very infertile sandy soils of the Mount Lofty Ranges, southern Yorke Peninsula, and Kangaroo Island in South Australia. Although only one area of nutrient-rich soils-the Wimmera District of Victoria-is located in southern Australia, the species 


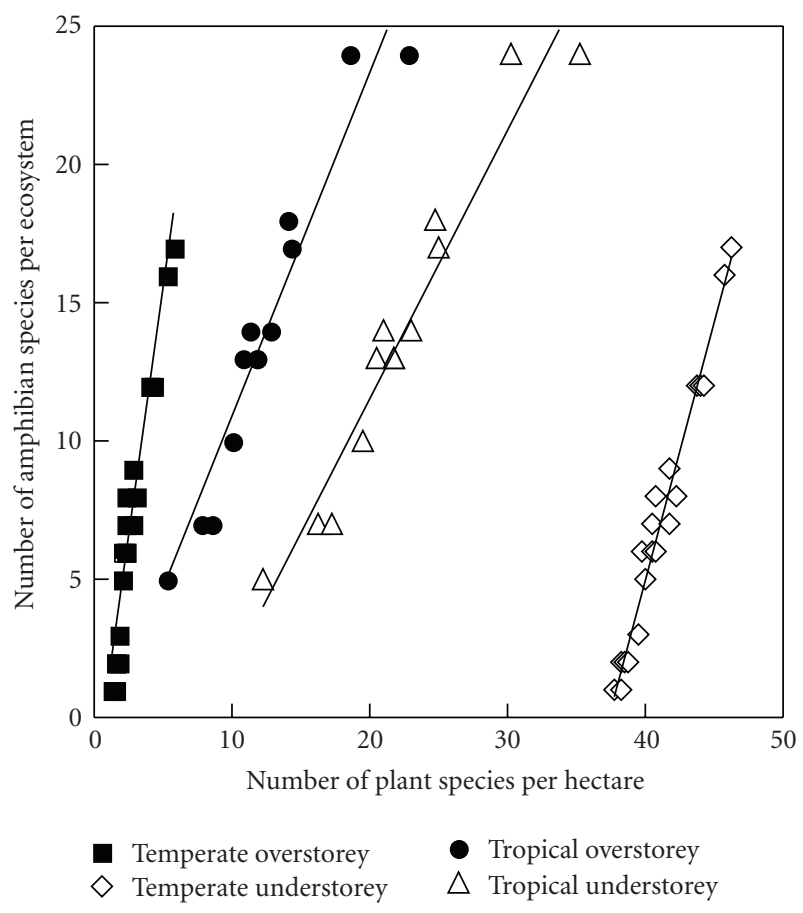

Figure 5: The relationship between species richness of overstorey and understorey plants in major plant communities with the biodiversity of Amphibia in associated wetlands in northern and southern Australia (Table 1). Temperate overstorey: Frogs $=3.59$ plants $-2.81\left(n=20 ; r^{2}=0.95\right)$. Temperate understorey: Frogs $=1.85$ plants $-69.2\left(n=20 ; r^{2}=0.97\right)$. Tropical overstorey: Frogs $=1.25$ plants $-1.58\left(n=13 ; r^{2}=0.93\right)$. Tropical understorey: Frogs $=0.97$ plants $-7.85\left(n=13 ; r^{2}=0.94\right)$.

richness of Amphibia in the Horsham-Nhill area is one to two species higher than on the medium-nutrient soils of south-eastern Australia (Figure 6(a)).

The higher temperatures (roughly $10^{\circ} \mathrm{C}$ greater) in the tropical north-in comparison with temperate southern Australia-induce even greater species richness of Amphibia (Figure 6(a)). The number of species markedly decreases in the macroclimatic gradient from the humid to the semiarid zone as observed in southern Australia. Soil nutrient status also affects species richness, with localities on the nutrientrich black soil plains in northern Australia supporting one or two species more than in wetlands on the mediumnutrient lateritic earths (Figure 6(a)). In inland sites (the "Red Centre") where the soils have been derived from nutrient-poor lateritic podsols, species richness is markedly reduced.

Amphibia living in wetland habitats derive most of their food from the solar energy fixed by the major Floristic Group of the area. When the species richness of Amphibia found in the major nutritional landscapes of temperate and tropical Australia (Figure 6(a)) is plotted against the biomass of leaves (ASG) produced annually on foliage shoots in each set of plant communities, a single linear regression line results (Figure 6(b)).

\section{Discussion}

4.1. Annual Foliage Shoot Growth (ASG, $t h a^{-1}$ ) in Overstorey Strata. The leaves of all evergreen overstorey and understorey plants in open-structured plant communities experience considerable stress during the long dry seasons experienced throughout Australia-during the winter months in the monsoonal north and during the summer months in the Mediterranean-type climate in the south. The leaves of C4-photosynthetic, perennial grasses that dominate the savanna (grassy) understorey may appear dead but show a remarkable power of cytoplasmic resurrection as soon as rains fall $[101,102]$.

The development and survival of the multitude of new leaves, which are produced annually in overstorey and understorey strata during the short periods of foliage growth in all life forms, are affected by turbulent aerodynamic fluxes (frictional, thermal, evaporative) in the atmosphere as it flows over and through a plant community.

Frictional forces "abrade" developing shoots at the edges of canopies of all component life forms in a plant community so that $\sum\left(\mathrm{FPC}_{o}+\mathrm{FPU}_{u}\right)$, the sum of the foliage projective covers of the overstorey $\left(\mathrm{FPC}_{o}\right)$ and understorey $\left(\mathrm{FPC}_{u}\right)$ strata, is a constant in space and time in both dryland and wetland ecosystems $[6,7,16,40]$.

Evaporative fluxes in the turbulent atmosphere above and within a plant community influence the movement of water in the transpiration stream that contains nitrogen and phosphorus ions. These nutrients are essential for the formation of high-energy compounds in mature leaves, from whence they are translocated to developing shoot apices to form the cytoplasmic contents and cell walls of new leaves. As "drag" (shearing stress) in the boundary layers above a plant community is minimal [103], the balance between cell wall to cytoplasm per unit area of mature leaf-leaf specific weight (LSW) - is constant in all overstorey and understorey strata $[6,16]$. It follows that stomatal resistances and carbon isotope ratios in the leaves of these strata will be representative of aerodynamic conditions during the seasonal periods of foliage shoot growth in each stratum.

Within the horizontal constraints of overstorey and understorey, defined by $\sum\left(\mathrm{FPC}_{o}+\mathrm{FPU}_{u}\right)$, the number of leaves produced vertically on developing foliage shoots is dependent on the flow of water and nutrients in the transpiration stream during the short period of shoot growth each year; a gradient in shoot elongation is apparent in overstorey trees as available water increases [6]. Ambient temperature during the period of active shoot growth also influences the number of leaves produced on foliage shoots in the $10^{\circ} \mathrm{C}$ gradient from temperate to tropical Australia. With more leaves per foliage shoot, the photosynthetic potential of the plant community is enhanced and results in increased annual growth (biomass per hectare) and determines the ultimate height of overstorey stratum in a plant community $[11,12,16]$.

The higher temperatures in northern Australia increase annual solar energy fixation by foliage in the overstorey stratum. As the main growth phenophases of understorey plants in northern Australia $[104,105]$ occur when solar 


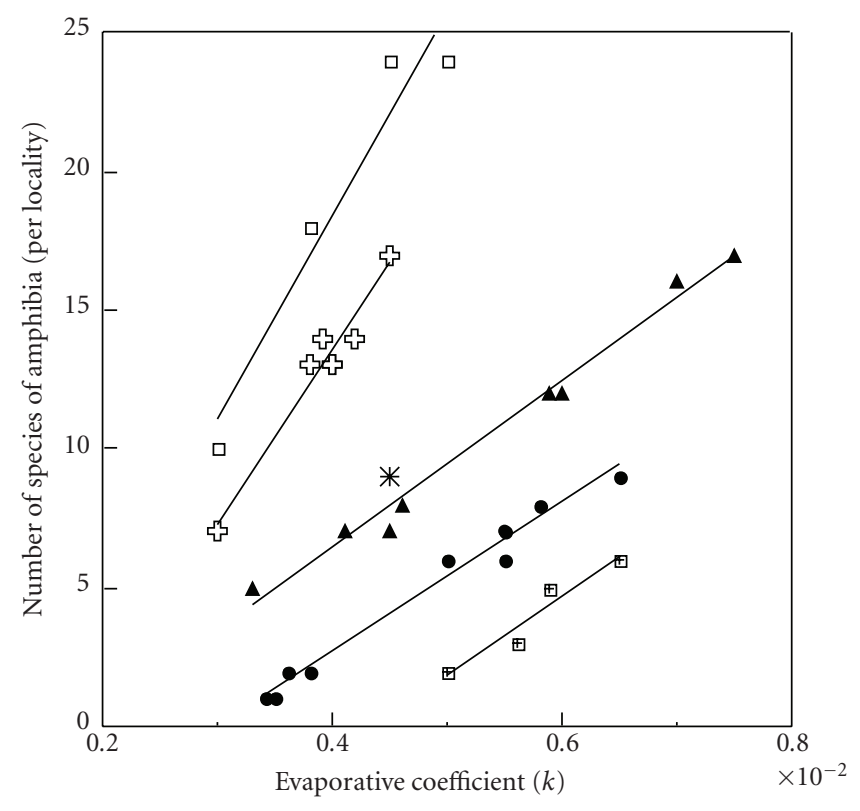

ㅁ Northern Australia (nutrient-rich)

§ Northern Australia (medium-nutrient)

* Wimmera, Victoria (nutrient-rich)

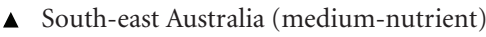

- South-west Australia (nutrient-poor)

๑ South Australia (extremely nutrient-poor)

(a)

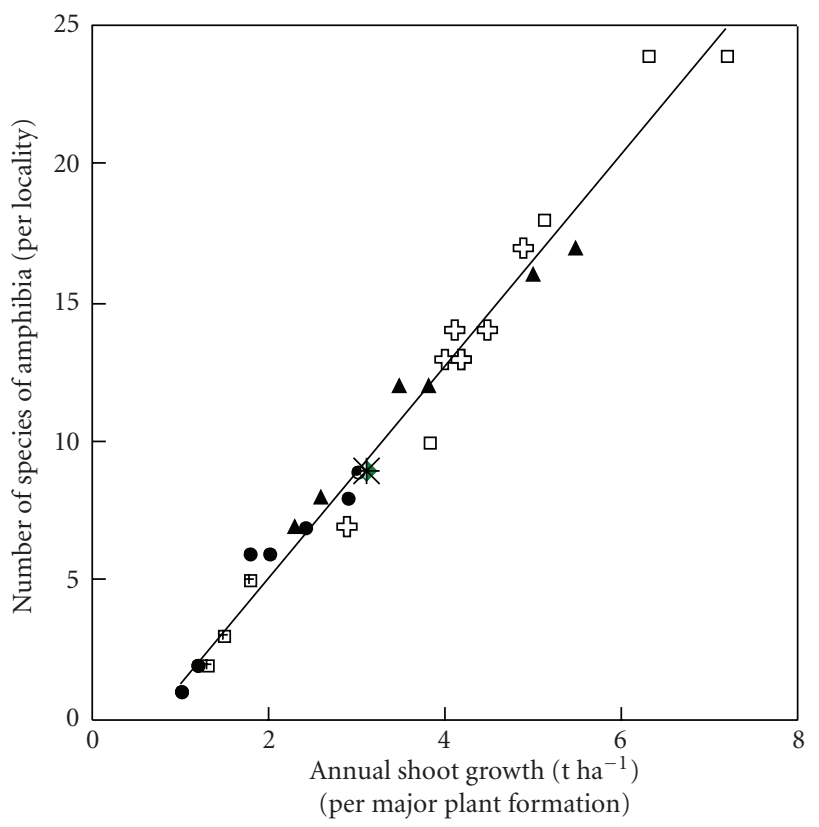

ㅁ Northern Australia (nutrient-rich)

§ Northern Australia (medium-nutrient)

* Wimmera, Victoria (nutrient-rich)

^ South-east Australia (medium-nutrient)

- South-west Australia (nutrient-poor)

甲 South Australia (extremely nutrient-poor)

(b)

Figure 6: (a) Number $(N)$ of species of Amphibians in nutrient-rich, medium-nutrient, nutrient-poor, and extremely nutrient-poor habitats in northern and southern Australia (Table 1), plotted against the Evaporative Coefficient $(k)$ of the sampling locality [26]. Perhumid climatic zone $-k>0.75 \times 10^{-2}$; humid climatic zone $-k=0.75-0.55 \times 10^{-2}$; subhumid climatic zone $-k=0.55-0.45 \times 10^{-2}$; semiarid climatic zone- $k=0.45-0.35 \times 10^{-2}$; arid climatic zone $-k<0.35 \times 10^{-2}$. Nutrient-rich soils (Nth Aust.): $N=0.737 \mathrm{k}-11.01\left(n=4, r^{2}=0.93\right)$. Medium-nutrient soils (Nth Aust.): $N=0.629 \mathrm{k}-11.61\left(n=6, r^{2}=0.94\right)$. Nutrient-rich soils (Vic.): $N=9$ when $k=0.45 \times 10^{-2}$ (only one site). Medium-nutrient soils (SE Aust.): $N=0.300 \mathrm{k}-5.59\left(n=8, r^{2}=0.98\right)$. Nutrient-poor soils (SW Aust.): $N=0.267 \mathrm{k}-7.99(n=9$, $\left.r^{2}=0.98\right)$. Extremely nutrient-poor soils (S.A.): $N=0.282 \mathrm{k}-12.22\left(n=4, r^{2}=0.93\right)$. (b) Number $(N)$ of species of Amphibians in nutrient-rich, medium-nutrient, nutrient-poor, and extremely nutrient-poor habitats in northern and southern Australia, plotted against the annual shoot growth (ASG, $\mathrm{t} \mathrm{ha}^{-1}$ ) of the major plant formation at the sampling site: $N=3.81$ ASG $-2.56\left(n=32, r^{2}=0.98\right)$.

radiation is essentially vertical $[12,16,106]$, high ambient temperatures in this stratum result in markedly higher stemroot respiration and thus affect the primary production of nonphotosynthetic organs $[11,12]$. In southern Australia where ambient temperatures are $10^{\circ} \mathrm{C}$ cooler than in the north and the sun's rays are oblique, annual growth (ASG, $\mathrm{t} \mathrm{ha}^{-1}$ ) of foliage shoots in both overstorey and understorey strata is reduced; however, as leaf respiration is lower in the cooler south than in the tropical north of Australia, net photosynthesis of each stratum is higher throughout the year $[11,12]$.

\subsection{Species Richness of Vascular Plants and Annual Foliage} Shoot Growth. In combination with aerodynamic fluxes, available soil water and soil nutrient status determine the fixation of solar energy as biomass (expressed as dry weight) of foliage shoots produced annually in every hectare of vegetation $[11,16,107,108]$. Species richness (number of species per hectare) and stem density (number of stems per hectare) of the overstorey of a plant community on medium-nutrient soils are exponentially correlated with annual shoot growth (ASG, $\mathrm{t} \mathrm{ha}^{-1}$ ) (Figure 4(a), after [11, $12,14-16,18]$.

In this paper, the species richness (number of species per hectare) of vascular plants in the nutrient-rich, medium-nutrient, nutrient-poor, and extremely nutrientpoor ecosystems (Figure 3(a)) of southern temperate and northern tropical Australia is plotted against annual shoot growth along the linear section, near the origin, of the exponential curve correlating species richness from the semiarid to the perhumid climatic zone in tropical, subtropical, and temperate Australia (Figure 4). These linear regressions indicate that the species richness of overstorey plants is higher in the tropics (5-23) than in temperate southern Australia (2-6); the inverse is found in understorey plants with 40-46 in temperate Australia and 12-35 species per hectare in monsoonal northern Australia.

The species richness of understorey plants in dryland plant communities is inversely related to the degree of 
shading produced by the foliage projective cover of the overstorey stratum $[5-7,40]$.

In wetland plant communities, however, species richness of overstorey and understorey strata both decreases as the number of months of waterlogging increases [7]. Nevertheless, the sum of foliage projective covers in the overstorey and understorey strata- $\sum\left(\mathrm{FPC}_{o}+\mathrm{FPU}_{u}\right)$-remains relatively constant along the wetland continuum [7].

Ambient temperature during the period of active shoot growth affects cell formation in developing leaves of the overstorey strata in the $10^{\circ} \mathrm{C}$ gradient from temperate to tropical Australia; increased species richness of overstorey strata (Figure 4(b)) appears to be associated with increased annual shoot growth (ASG, $\mathrm{t} \mathrm{ha}^{-1}$ ). On the other hand, the higher temperatures associated with almost vertical solar radiation in the north $[12,16,106]$, in contrast to the oblique, low-intensity rays in the south, result in higher leaf respiration (and, thus, reduced net photosynthesis) of this stratum throughout the year; a reduction in the species richness in the understorey stratum results (Figure 4(b)).

\subsection{Species Richness of Amphibia and Annual Foliage Shoot} Growth. Within each major plant community, the species richness (per plant community) of resident consumers (small mammals, birds, lizards, elapid snakes, and also Amphibia in associated wetlands) is also correlated with annual shoot growth $[16,17,23,24]$. As the different trophic levels of consumers are dependent on the energy fixed by the plant community, it follows that the species richness of these faunal groups will follow the species richness of plants in each ecosystem (Figure 5).

Most of the above surveys of the species richness of vertebrates associated with major plant communities were made in southern Australia on medium-nutrient soils; only the survey of small mammals by Braithwaite et al. [21] was made in the north. Pianka and Schall [109] did assemble data on the species richness of marsupials in grid squares with sides about $240 \mathrm{~km}$ long throughout Australia; their data are linearly correlated with the number of major plant communities recorded in each of their grid squares $[16,39]$.

This paper examines the species richness of Amphibia in both northern and southern Australia on a range of ecosystems from extremely nutrient-poor to nutrient-rich habitats (Figure 3(a)). The species richness of Amphibia shown by the five distinct linear regression lines of Figure 6(a) (plus that of the nutrient-rich Wimmera Region) coalesces when the data are plotted against the annual growth of foliage shoots (ASG, $\mathrm{t} \mathrm{ha}^{-1}$ ) of the major plant communities at each sampling site (Figure 6(b)).

4.4. Maintenance of Species Richness of Native Vascular Plants and Vertebrates. Over the last fifty million years, the original Gondwanan flora (rainforest flora \pm primitive eucalypts, temperate Nothofagus rainforest, savanna grasses, heathy plants, desert chenopods, etc.) has survived on the Australasian Tectonic Plate as it drifted northward from the subtropical Antarctic continent [16, 19, 110, 111]. The gradual development of the Southern Ocean between Antarctica and Australia induced an arid climate over much of the continent [112]; rainforests became confined to well-watered habitats, being replaced by open-structured vegetation across the continent.

The fixation of solar energy to produce foliage shoots (per hectare) in a plant community is obviously dependent on the macroclimate and soil fertility of the site. Any environmental change will affect the annual production of foliage shoots (per hectare) and, over a long period of time, result in a change in species richness of producers, consumers, and decomposers in the ecosystem [16, 113-117]. The reversal of ammonium production from decomposing litter in native ecosystems to that of nitrate production after disturbance $[13,118]$ enables the invasion of thin-leaved pioneers and introduced plants [119], further upsetting species richness of flora and fauna within an ecosystem [117].

As well, phosphate pollution on these soils has been demonstrated as a threat to the survival of much of the Australian heathland, savanna, and even rainforest vegetation and leads to the invasion of many exotic plants in the gaps that result $[16,24,36,38,115-117,120]$.

Nutrient transport, by run-off and seepage, into wetlands from undisturbed terrestrial plant communities, is minimal, especially as the majority of Australian soils contain a high percentage of kaolinite that fixes phosphate and molybdate ions within their clay lattice. Phosphate is conserved from leaching - as polyphosphate granules in roots and associated rhizosphere organisms when it is released as orthophosphate during the decomposition of leaf litter-in most of the Gondwanan-derived ecosystems [121-124]. Phosphate pollution in disturbed dry-land ecosystems surrounding a wetland, however, will accumulate in the surface organic layers of the soil [38] whence it can leak into drainage water [125] and affect the structure, growth, and biodiversity of wetland vegetation [126].

Changes in species richness of both plants and animals within most Australian ecosystems in conservation reserves $[19,127]$ will result if environmental perturbations affect the annual biomass production of a plant community. Global warming will increase the evaporative power of the atmosphere world-wide, independently of any change in rainfall; both $\sum\left(\mathrm{FPC}_{o}+\mathrm{FPU}_{u}\right)$ of the understorey and overstorey foliage and the ecomorphological attributes of leaves will be altered and influence primary productivity $[16,113,128]$. With a $2^{\circ} \mathrm{C}$ rise in global temperature, the structure of Australian plant communities, from the tropical north to the temperate south, will change: tall open-forest $\rightarrow$ open-forest $\rightarrow$ woodland $\rightarrow$ open-scrub $\rightarrow$ tall shrubland $\rightarrow$ low shrubland $\rightarrow$ desert.

Phosphate and nitrate pollution will induce marked changes in the Australian vegetation-savanna, heathland, and rainforest ecosystems - that has evolved on the nutrientpoor soils that covered much of Gondwanaland $[16,36,38$, $115-117,119]$.

An increase in the populations of soil chytrid fungi will be promoted by phosphate pollution (Figure 3(b), after [37]) and may pose a threat to Amphibia [129]. A total of 27 species belonging to the aquatic fungal group Chytridiales - all involved in the decomposition of cellulose, chitin, and keratin-were recorded in soil samples from 
southern Australia, from Perth to Wilson's Promontory, and as far inland as Alice Springs [33, 34, 37, 121, 130]. The easily cultured chytrid, Rhizophlyctis rosea, showed increased activity in soil samples whenever phosphate had been added as a fertiliser (Figure 3(b)). It must be expected that the input of phosphate pollution into wetlands from urban and rural communities will induce an increase in the activity of all chytrid species and thus may impose a threat to the survival of many individual frogs currently living in these habitats.

Exotic grazing animals (domestic animals, rabbits, etc.) prefer the thin-leaved plants that have occupied any disturbed site within the thick-leaved native plants that have survived and evolved in Australia during the last 100 million years [110]. Even the developing leaves of overstorey eucalypts and understorey shrubs, in habitats where the supply of high-energy phosphorus and nitrogen compounds is above normal, are more attractive to attack by small insects and mites $[6,131,132]$ — thus leading to increased allergic faecal dust in the atmosphere $[16,133,134]$.

Atmospheric salinity, blown inland by off-shore winds, will further affect annual shoot growth of C3-photosynthetic overstorey species and thus lead to a marked reduction in species richness $[16,135,136]$. Trace amounts of sodium, however, are essential for the C4-photosynthetic, perennial grasses and chenopods that dominate the savanna (grassy) understorey of tropical, subtropical, and even temperate Australia and in the vast Arid Zone of the continent [137, 138].

It is thus apparent that the species richness of the flora and fauna of the Gondwanan heritage of Australia is under threat from phosphate pollution, atmospheric salinity, and Global Warming. The first perturbation may lead to increased annual shoot growth (per hectare) and the last two perturbations to a reduction in annual shoot growth. Increased annual shoot growth of native plant communities leads to the invasion of exotic plants and animals; decreased annual shoot growth results in a reduction in species richness per hectare. The effect of these two perturbations on the ultimate composition and species richness of many Australian ecosystems needs intensive investigation.

An understanding of the physicochemical processes that operate within an entire ecosystem to maintain the species richness of the plant community (and associated consumers and decomposers) is essential for their scientific management.

\section{Acknowledgments}

The data presented here have been accumulated over many years as a result of research funding from several agencies. Mike Tyler would particularly like to acknowledge the support of the Australian Research Committee and the Utah Foundation. Information on the floristics of overstorey and understorey strata in plant communities has been published in ecological surveys made of every $30^{\prime}$ latitude $\times 30^{\prime}$ longitude grid cell throughout Australia. These data have been collated in sixteen large data banks and analysed by the classificatory program TWINSPAN [39]—with support from the Australian Heritage Commission.

\section{References}

[1] R. L. Specht, "The photosynthesis of plant communities in relation to structure, physiology and environment," Photosynthetica, vol. 1, pp. 132-134, 1967.

[2] J. A. Carnahan, "Natural vegetation. Map with accompanying booklet commentary," in Atlas of Australian Resources, Second Series, Department of National Resources, Canberra, Australia, 1976.

[3] R. L. Specht, "Vegetation," in The Australian Environment, G. W. Leeper, Ed., pp. 44-67, CSIRO \& Melbourne University Press, Melbourne, Australia, 4th edition, 1970.

[4] R. L. Specht, P. Rayson, and M. E. Jackman, "Dark Island heath (Ninety-Mile Plain, South Australia). 6. Pyric succession: changes in composition, coverage, dry weight and mineral nutrient status," Australian Journal of Botany, vol. 6, pp. 59-88, 1958.

[5] R. L. Specht and D. G. Morgan, "The balance between the foliage projective covers of overstorey and understorey strata in Australian vegetation," Australian Journal of Ecology, vol. 6, pp. 193-202, 1981.

[6] R. L. Specht, G. N. Batianoff, and R. D. Reeves, "Vegetation structure and biodiversity along the eucalypt forest to rainforest continuum on the serpentinite soil catena in a subhumid area of Central Queensland, Australia," Austral Ecology, vol. 31, no. 3, pp. 394-407, 2006.

[7] R. L. Specht, "Structure and species richness in wetland continua on sandy soils in subtropical and tropical Australia," Austral Ecology, vol. 34, no. 7, pp. 761-772, 2009.

[8] R. L. Specht and P. W. Rundel, "Sclerophylly and foliar nutrient status of mediterranean-climate plant communities in southern Australia," Australian Journal of Botany, vol. 38, no. 5, pp. 459-474, 1990.

[9] R. L. Specht and A. Specht, "The ratio of foliar nitrogen to foliar phosphorus: a determinant of leaf attributes and height in life-forms of subtropical and tropical plant communities," Australian Journal of Botany. In press.

[10] R. L. Specht and Y. M. Brouwer, "Seasonal shoot growth of Eucalyptus spp. in the Brisbane area of Queensland (with notes on shoot growth and litter fall in other areas of Australia)," Australian Journal of Botany, vol. 23, pp. 459-474, 1975.

[11] R. L. Specht and A. Specht, "Canopy structure in Eucalyptusdominated communities in Australia along climatic gradients," Acta Oecologica, Oecology of Plants, vol. 10, pp. 191202, 1989.

[12] R. L. Specht and A. Specht, "Species richness of overstorey strata in Australian plant communities-the influence of overstorey growth rates," Australian Journal of Botany, vol. 37, no. 4, pp. 321-336, 1989.

[13] E. E. Hegarty, "Leaf life-span and leafing phenology of lianes and associated trees during a rainforest succession," Journal of Ecology, vol. 78, no. 2, pp. 300-312, 1990.

[14] A. Specht and R. L. Specht, "Species richness and canopy productivity of Australian plant communities," Biodiversity and Conservation, vol. 2, no. 2, pp. 152-167, 1993.

[15] A. Specht and R. L. Specht, "Biodiversity of overstorey trees in relation to canopy productivity and stand density in the climatic gradient from warm temperate to tropical Australia," Biodiversity Letters, vol. 2, no. 2, pp. 39-45, 1994.

[16] R. L. Specht and A. Specht, Australian Plant Communities. Dynamics of Structure, Growth and Biodiversity, Oxford University Press, Melbourne, Australia, 1999. 
[17] R. L. Specht, "Species richness of vascular plants and vertebrates in relation to canopy productivity," in PlantAnimal Interactions in Mediterranean-Type Ecosystems, M. Arianoutsou and R. H. Groves, Eds., pp. 15-24, Kluwer Scientific Publications, Dordrecht, The Netherlands, 1994.

[18] R. L. Specht and A. Specht, "Species richness of sclerophyll (heathy) plant communities in Australia-the influence of overstorey cover," Australian Journal of Botany, vol. 37, no. 4, pp. 337-350, 1989.

[19] R. L. Specht and M. E. Dettmann, "Palaeoecology of Australia and current physiological functioning of plant communities," in Time Scales of Biological Responses to Water Constraints, J. Roy, J. Aronson, and F. di Castri, Eds., pp. 201-214, SBS Academic Publishing, Amsterdam, The Netherlands, 1995.

[20] K. H. Northcote, et al., Atlas of Australian Soils. Sheets 1-10, Australia's Commonwealth Scientific and Industrial Research Organisation (CSIRO), Mebourne University Press, Melbourne, Australia, 1960-1968.

[21] R. W. Braithwaite, J. W. Winter, J. A. Taylor, and B. S. Parker, "Patterns of diversity and structure of mammalian assemblages in the Australian tropics," Australian Mammal Society, vol. 8, pp. 171-186, 1985.

[22] P. C. Catling, "Vertebrates," in Mediterranean-Type Ecosystems. A Data Source Book, R. L. Specht, Ed., pp. 171-196, Kluwer Academic Publishers, Dordrecht, The Netherlands, 1988.

[23] R. L. Specht, "Climatic control of eco-morphological characters and species richness in mediterranean ecosystems," in Mediterranean-Type Ecosystems. A Data Source Book, R. L. Specht, Ed., pp. 149-155, Kluwer Academic Publishers, Dordrecht, The Netherlands, 1988.

[24] A. Specht, "Big scrub conservation strategy," in Resource Material, vol. 2, pp. 2.1-2.72, New South Wales National Parks and Wildlife Service, Sydney, Australia, 1988, Edited by Planners North Pty Ltd.

[25] H. C. T. Stace, G. D. Hubble, R. Brewer, et al., A Handbook of Australian Soils, Rellim Technical Publications, Glenside, South Australia, 1968.

[26] R. L. Specht, "Water use by perennial, evergreen plant communities in Australia and Papua New Guinea," Australian Journal of Botany, vol. 20, pp. 273-299, 1972.

[27] R. L. Specht, The Vegetation of South Australia, Government Printer, Adelaide, Australia, 1972.

[28] R. L. Specht, "Growth indices-their rôle in understanding the growth, structure and distribution of Australian vegetation," Oecologia, vol. 50, no. 3, pp. 347-356, 1981.

[29] R. L. Specht, "Dark Island heath (Ninety-Mile Plain, South Australia). 4. Soil moisture patterns produced by rainfall interception and stem-flow," Australian Journal of Botany, vol. 5, pp. 137-150, 1957.

[30] R. L. Specht, "Dark Island heath (Ninety-Mile Plain, South Australia). 5. The water relationships in heath vegetation and pastures on the Makin sand, South Australia," Australian Journal of Botany, vol. 5, pp. 151-172, 1957.

[31] H. A. Martin and R. L. Specht, "Are mesic communities less drought resistant? A study on moisture relationships in dry sclerophyll forest at Inglewood, South Australia," Australian Journal of Botany, vol. 10, pp. 106-118, 1962.

[32] B. B. Carrodus, Some aspects of the ecology of arid South Australia. The relative distribution of Atriplex vesicaria and Kochia sedifolia, M.S. thesis, University of Adelaide, Adelaide, Australia, 1962.
[33] R. Jones, "The leaf area of an Australian heathland with reference to seasonal changes and the contribution of individual species," Australian Journal of Botany, vol. 16, pp. 579-588, 1968.

[34] R. L. Specht and R. Jones, "A comparison of the water use by heath vegetation at Frankston, Victoria and Dark Island Soak, South Australia," Australian Journal of Botany, vol. 19, pp. 311-326, 1971.

[35] E. A. Fitzpatrick, "Estimates of pan evaporation from mean maximum temperature and vapour pressure," Journal of Applied Meteorology, vol. 2, pp. 780-792, 1963.

[36] R. L. Specht, "Dark Island heath (Ninety-Mile Plain, South Australia). 7. The effect of fertilizers on composition and growth, 1950-60," Australian Journal of Botany, vol. 11, pp. 67-94, 1963.

[37] L. G. Willoughby, "A study of Chytridiales from Victorian and other Australian soils," Archiv für Mikrobiologie, vol. 52, no. 2, pp. 101-131, 1965.

[38] E. M. Heddle and R. L. Specht, "Dark Island heath (NinetyMile Plain, South Australia). 8. The effect of fertilizers on composition and growth, 1950-1972," Australian Journal of Botany, vol. 23, pp. 151-164, 1975.

[39] R. L. Specht, A. Specht, M. B. Whelan, and E. E. Hegarty, Conservation Atlas of Plant Communities in Australia, Southern Cross University, Lismore, NSW, Australia, 1995.

[40] R. L. Specht, "Foliage projective covers of overstorey and understorey strata of mature vegetation in Australia," Australian Journal of Ecology, vol. 8, no. 4, pp. 433-439, 1983.

[41] P. K. Gullan, N. G. Walsh, and S. J. Forbes, "Vegetation in the Gippsland lakes catchment," Muelleria, vol. 4, pp. 333-383, 1981.

[42] P. K. Gullan, S. J. Forbes, G. E. Earl, R. H. Barley, and N. G. Walsh, "Vegetation of south and central Gippsland," Muelleria, vol. 6, no. 2, pp. 97-145, 1985.

[43] J. C. Wombey, "Reptiles and Amphibia," in MediterraneanType Ecosystems. A Data Source Book, R. L. Specht, Ed., p. 193, Kluwer Academic Publishers, Dordrecht, The Netherlands, 1988.

[44] T. G. B. Osborn and R. N. Robertson, "A reconnaissance survey of the vegetation of the Myall Lakes," Proceedings of the Linnean Society of New South Wales, vol. 64, pp. 279-296, 1939.

[45] B. J. Fox, "Fire and mammalian secondary succession in an Australian coastal heath," Ecology, vol. 63, no. 5, pp. 1332$1341,1982$.

[46] L. D. Adams and L. A. Craven, "Checklist of vascular plants in a study area of the south coast of N.S.W.," Technical Memorandum 76/16, Australia's Commonwealth Scientific and Industrial Research Organisation (CSIRO), Division of Land Use Research, Canberra, Australia, 1976.

[47] M. P. Austin and J. Sheaffe, "Vegetation survey data of the south coast study area, N.S.W.," Technical Memorandum 76/15, Australia's Commonwealth Scientific and Industrial Research Organisation (CSIRO), Division of Land Use Research, Canberra, Australia, 1976.

[48] A. E. Newsome and P. C. Catling, "Habitat preferences of mammals inhabiting heathlands of warm temperate coastal, montane and alpine regions of south-eastern Australia," in Ecosystems of the World, R. L. Specht, Ed., vol. 9 of Heathlands and Related Shrublands. Descriptive Studies, pp. 301-316, Elsevier, Amsterdam, The Netherlands, 1979. 
[49] J. W. Audas, "The Victorian Grampians (a botanical retrospect)," Victorian Naturalist, vol. 63, pp. 136-139, 1946.

[50] J. Frankenberg, Nature Conservation in Victoria, Victorian National Parks Association, Melbourne, Australia, 1971.

[51] D. Frood and M. Calder, Nature Conservation in Victoria, vol. 2, Victorian National Parks Association, Melbourne, Australia, 1987.

[52] M. J. Tyler, Australian Frogs: A Natural History, Reed, Sydney, Australia, 1994.

[53] J. N. Rowan and R. G. Downes, "A study of the land in North Western Victoria," Soil Conservation Authority of Victoria Technical Communication 2, Soil Conservation Authority of Victoria, Kew, Victoria, 1963.

[54] R. W. Jessup, "A vegetation and pasture survey of Counties Eyre, Burra and Kimberley, South Australia," Transactions of the Royal Society of South Australia, vol. 72, pp. 33-68, 1948.

[55] D. J. Connor, "Vegetation studies in North-west Victoria. II. The Horsham area," Proceedings of the Royal Society of Victoria, vol. 79, pp. 579-595, 1966.

[56] F. G. Smith, "Vegetation Survey of Western Australia 1:250,000 Series: Pemberton and Irwin Inlet," Busselton and Augusta, Collie. Western Australian Department of Agriculture, Perth, Australia, 1972-1974.

[57] J. S. Beard, Vegetation Survey of Western Australia. Sheet 7. Swan, University of Western Australia, Press, Nedlands, Australia, 1981.

[58] A. S. Weston, "Vascular plants of the karri forest and the Reservoir Site," Consultancy Report. In press.

[59] P. Christensen, A. Annels, G. Liddelow, and P. Skinner, Vertebrate Fauna in the Southern Forests of Western Australia. A Survey, Western Australian Forestry Department Bulletin No. 94, 1985.

[60] D. Daze, A Bibliography and Research Inventory of Vertebrate Fauna in Western Australia, Department of Conservation and Environment, Perth, Australia, 1984.

[61] M. J. Tyler, L. A. Smith, and R. E. Johnstone, Frogs of Western Australia, Western Australian Museum, Perth, Australia, 1984.

[62] R. F. Williams, "An ecological analysis of the plant communities of the 'Jarrah' Region occurring in a small area near Darlington," Journal of The Royal Society of Western Australia, vol. 18, pp. 105-124, 1931-1932.

[63] A. Chapman, J. Dell, D. J. Kitchener, and B. G. Muir, "Biological survey of the western Australian wheatbelt. Part 5. Dongolocking Nature Reserve," Records of the Western Australian Museum, supplement 6, pp. 7-80, 1978.

[64] J. S. Beard and M. J. Webb, Vegetation Survey of Western Australia. Sheet 2. Great Sandy Desert, University of Western Australia, Press, Nedlands, Australia, 1974.

[65] J. Dell, R. A. How, K. R. Newbey, and R. J. Hnatiuk, "The biological survey of the Eastern goldfields of Western Australian. Part 3. Jackson-Kalgoorlie study area," Records of the Western Australian Museum, supplement 23, pp. 1-168, 1985.

[66] B. G. Muir, A. Chapman, J. Dell, and D. J. Kitchener, "Biological survey of the western Australian wheatbelt. Part 6. Durokoppin and Kodj Kodjin Nature Reserves," Records of the Western Australian Museum, supplement 7, pp. 9-77, 1978.

[67] J. Dell, A. Chapman, D. J. Kitchener, D. J. McGauran, and B. G. Muir, "Biological survey of the Western Australian wheatbelt. Part 14. East Yuna and Bindoo Hill Nature Reserves," Records of the Western Australian Museum, supplement 13, pp. 9-105, 1981.
[68] D. Monk, R. J. Hnatiuk, and A. S. George, "Vegetation survey of Frank Hann National Park," Western Australian Herbarium Research Notes, vol. 2, pp. 23-49, 1979.

[69] A. S. George, A. J. M. Hopkins, and N. G. Marchant, "The heathlands of Western Australia," in Ecosystems of the World, R. L. Specht, Ed., vol. 9 of Heathlands and Related Shrublands. Descriptive Studies, pp. 211-230, Elsevier, Amsterdam, The Neherlands, 1979.

[70] R. L. Specht and R. A. Perry, "Plant ecology of part of the Mount Lofty Ranges," Transactions of the Royal Society of South Australia, vol. 72, pp. 91-132, 1948.

[71] H. A. Martin and R. L. Specht, "Sclerophyll (heathy) understoreys in the Mount Lofty Ranges, South Australia," Transactions of the Royal Society of South Australia, vol. 129, no. 1, pp. 14-24, 2005.

[72] J. G. Wood, "An analysis of the vegetation of Kangaroo Island and the adjacent peninsulas," Transactions of the Royal Society of South Australia, vol. 54, pp. 105-139, 1930.

[73] J. G. Baldwin and R. L. Crocker, "The soils and vegetation of portion of Kangaroo Island, South Australia," Transactions of the Royal Society of South Australia, vol. 65, pp. 263-275, 1941.

[74] R. J.-P. Davies, The Conservation of Major Plant Associations in South Australia, Conservation Council of South Australia, Adelaide, Australia, 1982.

[75] M. R. Foale, Ed., The Vegetation of Yorke Peninsula, Nature Conservation Society of South Australia, Adelaide, Australia, 1977.

[76] R. L. Specht and P. Rayson, "Dark Island heath (NinetyMile Plain, South Australia). 1. Definition of the ecosystem," Australian Journal of Botany, vol. 5, pp. 103-114, 1957.

[77] R. L. Specht, "Climate, geology, soils and plant ecology of the northern portion of Arnhem Land," in Records of the American-Australian Expedition to Arnhem Land, R. L. Specht and C. P. Mountford, Eds., vol. 3 of Botany and Plant Ecology, pp. 333-414, Melbourne University Press, Melbourne, Australia, 1958.

[78] B. A. Wilson, P. S. Brocklehurst, M. J. Clark, and K. J. M. Dickerson, "Vegetation Survey of the Northern Territory, Australia," Conservation Commission of the Northern Territory Technical Report 49, Conservation Commission of the Northern Territory, Darwin, Australia, 1990.

[79] M. J. Tyler, G. A. Crook, and M. Davies, "Reproductive biology of the frogs of the Magela Creek System, Northern Territory," Records of the South Australian Museum, vol. 18, pp. 415-440, 1983.

[80] C. S. Christian and G. A. Stewart, General Report on Survey of the Katherine-Darwin Region, 1946, Land Research Series No. 1, Australian Commonwealth Scientific and Research Organization (CSIRO), Division of Land Use Research, Canberra, Australia, 1953.

[81] M. J. Tyler and M. Davies, Frogs of the Northern Territory, Conservation Commission of the Northern Territory, Alice Springs, Australia, 1986.

[82] R. A. Perry and C. S. Christian, Vegetation of the Barkly Region, Northern Territory and Queensland, Land Research Series No. 3, Australia's Commonwealth Scientific and Industrial Research Organisation (CSIRO), Melbourne, Australia, 1954.

[83] M. J. Tyler, M. Davies, and A. A. Martin, "The frog fauna of the Barkly Tableland, Northern Territory," Transactions of the Royal Society of South Australia, vol. 107, pp. 237-242, 1983. 
[84] N. H. Speck, Vegetation of the North Kimberley Area, Western Australia, Land Research Series No. 4, Australian Commonwealth Scientific and Research Organization (CSIRO), Division of Land Use Research, Canberra, Australia, 1960.

[85] R. A. Perry, Vegetation of the Ord-Victoria Area, Land Research Series No. 28, Australia's Commonwealth Scientific and Industrial Research Organisation (CSIRO), Canberra, Australia, 1970.

[86] J. S. Beard, Vegetation Survey of Western Australia. Sheet 1. Kimberley, University of Western Australia, Press, Nedlands, Australia, 1979.

[87] M. J. Tyler, M. Davies, and G. F. Watson, "The frog fauna of Melville Island, Northern Territory," The Beagle, vol. 8, pp. $1-10,1991$.

[88] B. A. Wilson, The open-forest "Treeless" plains boundary on Melville Island, Northern Territory, M.S. thesis, University of Tasmania, Tasmania, Australia, 1991.

[89] N. H. Speck and M. Lazarides, Vegetation and Pastures of the West Kimberley Area, Land Research Series No. 9, Australian Commonwealth Scientific and Research Organization (CSIRO), Division of Land Use Research, Canberra, Australia, 1964.

[90] M. J. Tyler, M. Davies, and G. F. Watson, "Frogs of the Gibb river road, Kimberley division, Western Australia," Records of the Western Australian Museum, vol. 13, pp. 541-552, 1987.

[91] R. A. Perry and M. Lazarides, Vegetation of the Alice Springs Area, Northern Territory, Land Research Series No. 6, Australia's Commonwealth Scientific and Industrial Research Organisation (CSIRO), Melbourne, Australia, 1962.

[92] Australian Water Resources Council, Review of Australia's Water Resources, Australian Government Publishing Services, Canberra, Australia, 1976.

[93] R. L. Specht, R. B. Salt, and S. Reynolds, "Vegetation in the vicinity of Weipa, North Queensland," Proceedings of the Royal Society of Queensland, vol. 88, pp. 17-38, 1977.

[94] P. Jaccard, "Die statistische-floristische methode als. Grundlage der pflanzensoziologie," in Abderhalden's Handbuch der Biologischen. Arbeitsmethoden, vol. 5, pp. 165-202, 1928.

[95] J. Braun-Blanquet, Plant Sociology, McGraw-Hill, New York, NY, USA, 1932.

[96] G. Long, Diagnostic Phyto-Écologique et Aménagement du Territoire, Masson, Paris, France, 1974.

[97] C. S. Christian, "Regional land surveys," Australian Journal of Agricultural Research, vol. 18, pp. 140-146, 1952.

[98] C. S. Christian and R. A. Perry, "The systematic description of plant communities by the use of symbols," Journal of Ecology, vol. 41, pp. 100-105, 1953.

[99] M. O. Hill, "Reciprocal averaging: an eigen vector method of ordination," Journal of Ecology, vol. 61, pp. 237-249, 1973.

[100] R. L. Specht, Ed., Mediterranean-Type Ecosystems. A Data Source Book, Kluwer Academic Publishers, Dordrecht, The Netherlands, 1988.

[101] D. J. Doley and N. B. A. Trivett, "Effects of low water potentials on transpiration and photosynthesis in Mitchell grass (Astrebla lappacea)," Australian Journal of Plant Physiology, vol. 1, pp. 539-550, 1974.

[102] C. J. Mittelheuser, "Rapid ultrastructural recovery of water stressed leaf tissue," Zeitschrift für Pflanzenphysiologie, vol. 82, pp. 458-461, 1977.

[103] J. K. Marshall, "Drag measurements in roughness arrays of varying density and distribution," Agricultural Meteorology, vol. 8, no. C, pp. 269-292, 1971.
[104] R. L. Specht, "Functioning of tropical plant communities: phenology," in Tropical Plant Communities. Their Resilience, Functioning and Management in Northern Australia, H. T. Clifford and R. L. Specht, Eds., pp. 78-90, Utah Foundation \& Botany Department, University of Queensland, St Lucia, Queensland, 1986.

[105] R. J. Williams, B. A. Myers, W. J. Muller, G. A. Duff, and D. Eamus, "Leaf phenology of woody species in a North Australian tropical savanna," Ecology, vol. 78, no. 8, pp. 25422558, 1997.

[106] F. Loewe, The Intake of Solar Radiation by Slopes, with Cloudless Sky, Bulletin No. 45, Commonwealth of Australia, Bureau of Meteorology, 1962.

[107] R. L. Specht, R. I. Grundy, and A. Specht, "Species richness of plant communities: relationship with community growth and structure," Israel Journal of Botany, vol. 39, no. 4-6, pp. 465-480, 1990.

[108] R. L. Specht, H. T. Clifford, M. Arianoutsou, et al., "Structure, floristics and species richness of plant communities in southeast Queensland," Proceedings of the Royal Society of Queensland, vol. 101, pp. 27-78, 1991.

[109] E. R. Pianka and J. J. Schall, "Species densities of Australian vertebrates," in Ecological Biogeography of Australia, A. Keast, Ed., pp. 1675-1694, Junk, The Hague, The Netherlands, 1981.

[110] R. L. Specht, M. E. Dettmann, and D. M. Jarzen, "Community associations and structure in the Late Cretaceous vegetation of southeast Australasia and Antarctica," Palaeogeography, Palaeoclimatology, Palaeoecology, vol. 94, no. 1-4, pp. 283-309, 1992.

[111] H. A. Martin, "The Tertiary flora," in Ecological Biogeography of Australia, A. Keast, Ed., pp. 391-406, Junk, The Hague, The Netherlands, 1981.

[112] H. A. Martin, "Cenozoic climatic change and the development of the arid vegetation in Australia," Journal of Arid Environments, vol. 66, no. 3, pp. 533-563, 2006.

[113] R. L. Specht and A. Specht, "Global warming: predicted effects on structure and species richness of mediterranean ecosystems in southern Australia," in Time Scales of Biological Responses to Water Constraints: The Case of Mediterranean Biota, J. Roy, J. Aronson, and F. di Castri, Eds., pp. 215-237, SPB Academic Publishing, Amsterdam, The Netherlands, 1995.

[114] A. Specht and R. L. Specht, "Ecosystems of Australia," in Encyclopedia of Biodiversity, M. Levin, Ed., vol. 1, pp. 307324, Academic Press, San Diego, Calif, USA, 2001.

[115] R. L. Specht, "Savanna woodland vegetation in the southeast district of South Australia: the influence of evaporative aerodynamics on the foliage structure of the understorey invaded by introduced annuals," Austral Ecology, vol. 25, no. 6, pp. 588-599, 2000.

[116] R. L. Specht, "Phosphorus toxicity and pollution: a threat to our Gondwanan heritage," Ecological Management and Restoration, vol. 2, no. 3, pp. 228-230, 2001.

[117] R. L. Specht, "Phosphate pollution and soil nitrate: threats to biodiversity in Australia," in Landscape Health of Queensland, A. J. Franks, J. Playford, and A. Shapcott, Eds., pp. 53-70, Royal Society of Queensland, Brisbane, Queensland, 2002.

[118] D. Lamb, "Soil nitrogen mineralisation in a secondary rainforest succession,” Oecologia, vol. 47, no. 2, pp. 257-263, 1980.

[119] G. R. Stewart, C. A. Gracia, E. E. Hegarty, and R. L. Specht, "Nitrate reductase activity and chlorophyll content in sun leaves of subtropical Australian closed-forest (rainforest) and 
open-forest communities," Oecologia, vol. 82, no. 4, pp. 544$551,1990$.

[120] P. G. Ozanne and R. L. Specht, "Mineral nutrition of heathlands: phosphorus toxicity," in Ecosystems of the World, R. L. Specht, Ed., vol. 9 of Heathlands and Related Shrublands. Analytical Studies, pp. 209-213, Elsevier, Amsterdam, The Netherlands, 1981.

[121] R. L. Specht and R. H. Groves, "A comparison of the phosphorus nutrition of Australian heath plants and introduced economic plants," Australian Journal of Botany, vol. 14, pp. 201-221, 1966.

[122] D. W. Jeffrey, "Phosphate nutrition of Australian heath plants. II. The formation of polyphosphate by five heath species," Australian Journal of Botany, vol. 15, pp. 403-412, 1968.

[123] R. G. Coleman and R. L. Specht, "Mineral nutrition of heathlands. The possible role of polyphosphate in the phosphorus economy of heathland species," in Ecosystems of the World, R. L. Specht, Ed., vol. 9 of Heathlands and Related Shrublands. Analytical Studies, pp. 197-207, Elsevier, Amsterdam, The Netherlands, 1981.

[124] R. L. Specht, E. J. Moll, F. Pressinger, and J. Sommerville, "Moisture regime and nutrient control of seasonal growth in mediterranean ecosystems," in Mediterranean-Type Ecosystems. The Role of Nutrients, F. J. Kruger, D. T. Mitchell, and J. U. M. Jarvis, Eds., pp. 120-132, Springer, Berlin, Germany, 1983.

[125] P. J. Bliss, S. J. Riley, and D. Adamson, "Towards rational guidelines for urban storm-water release into flora preservation areas," The Shire and Municipal Record, vol. 75, pp. 181185, 1983.

[126] R. L. Specht, "Forested wetlands in Australia," in Ecosystems of the World, A. E. Lugo, M. M. Brinson, and S. Brown, Eds., vol. 16 of Wetland Forests, pp. 387-406, Elsevier, Amsterdam, The Netherlands, 1990.

[127] R. L. Specht, E. M. Roe, and V. H. Boughton, "Conservation of major plant communities in Australia and Papua New Guinea," Australian Journal of Botany Supplement Series, supplement 7, 1974.

[128] R. L. Specht, "Geosphere-biosphere interaction in terrestrial ecosystems," in Global Change, K. D. Cole, Ed., pp. 169-176, Australian Academy of Science, Canberra, Australia, 1988.

[129] L. Berger, R. Speare, P. Daszak et al., "Chytridiomycosis causes amphibian mortality associated with population declines in the rain forests of Australia and Central America," Proceedings of the National Academy of Sciences of the United States of America, vol. 95, no. 15, pp. 9031-9036, 1998.

[130] R. H. Groves and R. L. Specht, "Growth of heath vegetation. 1. Annual growth curves of two heath ecosystems in Australia," Australian Journal of Botany, vol. 13, pp. 261-280, 1965.

[131] S. J. Edmonds and M. M. Specht, "Dark Island heathland, South Australia: faunal rhythms," in Ecosystems of the World, R. L. Specht, Ed., vol. 9 of Heathlands and Related Shrublands. Analytical Studies, pp. 15-241, Elsevier, Amsterdam, The Netherlands, 1981.

[132] M. M. Specht and R. L. Specht, "Herbivory of leaves of Banksia oblongifolia, with or without overstorey cover," in Plant-Animal Interactions in Mediterranean-type Ecosystems, C. A. Thanos, Ed., pp. 22-27, University of Athens, Athens, Greece, 1991.

[133] R. L. Specht, Y. M. Brouwer, and E. H. Derrick, "Seasonal waves of asthma: a possible botanical cause," International Journal of Biometeorology, vol. 19, no. 1, pp. 28-36, 1975.
[134] A. Specht and I. M. Whyte, "Air spora studies in vegetation in Brisbane and its possible relationships with asthma," in Proceedings Interasma V Congress (INTERASMA '78), Torremolinos, Spain, 1978.

[135] A. Rich, What is Littoral about Rainforest?, B. Applied Sc. Hons. Thesis, Southern Cross University, Lismore, Autralia, 1996.

[136] R. L. Specht, "Species richness of rainforest stands on nonserpentinite and serpentinite substrates in the Rockhampton -Marlborough area of Central Queensland," Proceedings of the Royal Society of Queensland, vol. 113, pp. 17-35, 2007.

[137] P. F. Brownell, "Sodium as an essential micro-nutrient for a higher plant (Atriplex vesicaria)," Plant Physiology, vol. 40, pp. 460-468, 1965.

[138] P. F. Brownell and C. J. Crossland, "The requirement of sodium as a micro-nutrient by species having the $\mathrm{C}_{4}$ dicarboxylic photosynthetic pathway," Plant Physiology, vol. 49, pp. 794-797, 1972. 

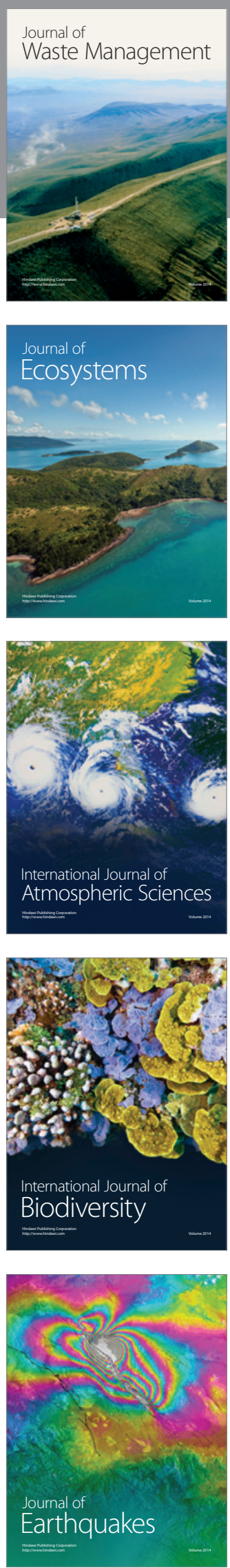
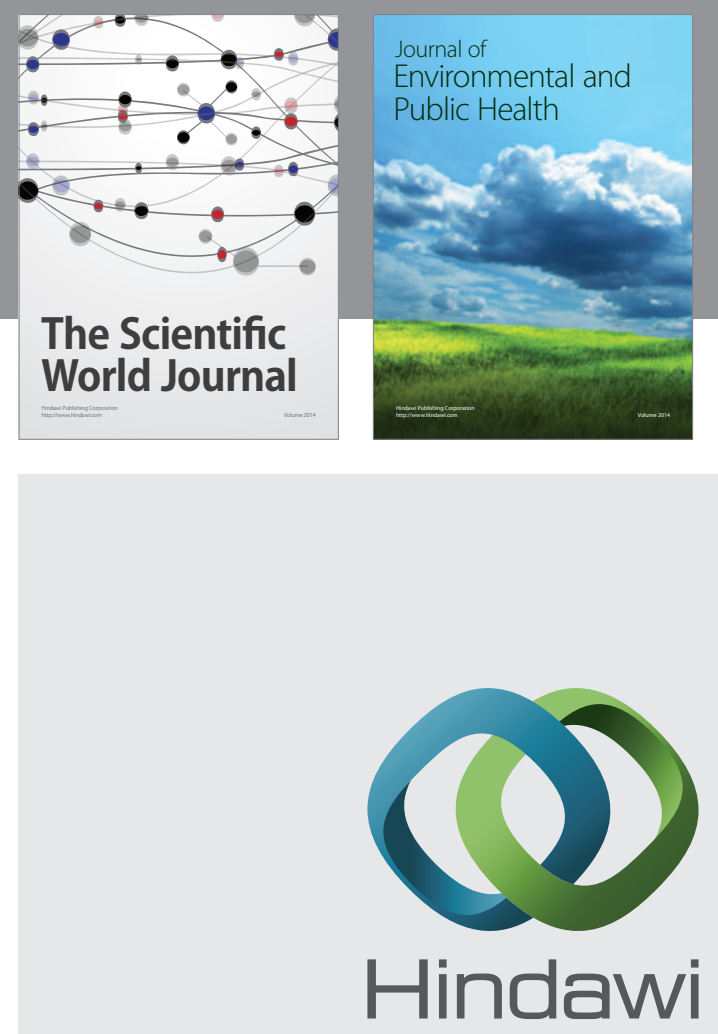

Submit your manuscripts at

http://www.hindawi.com
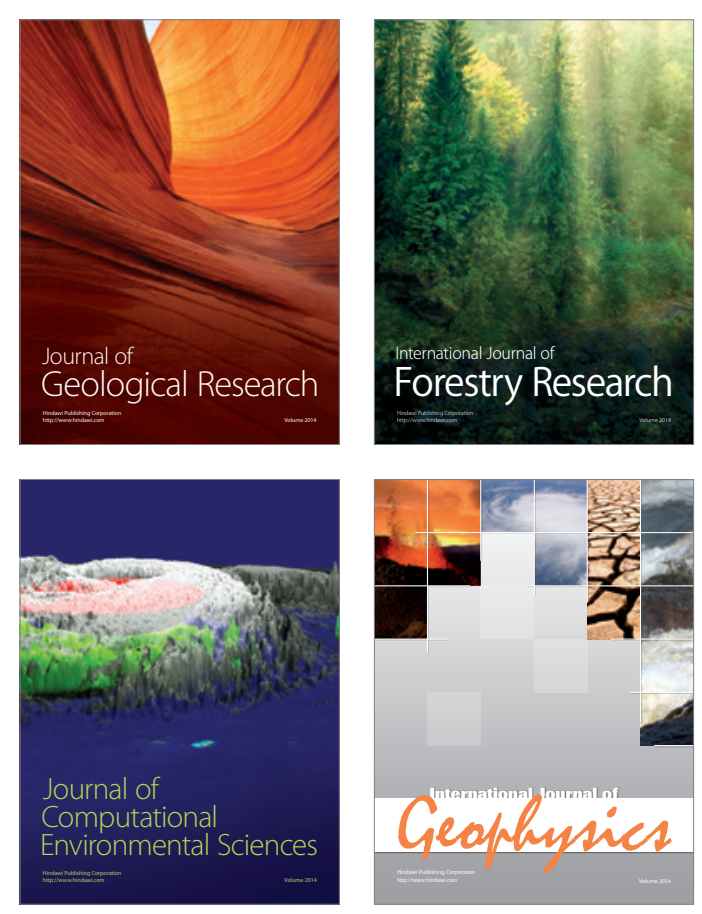
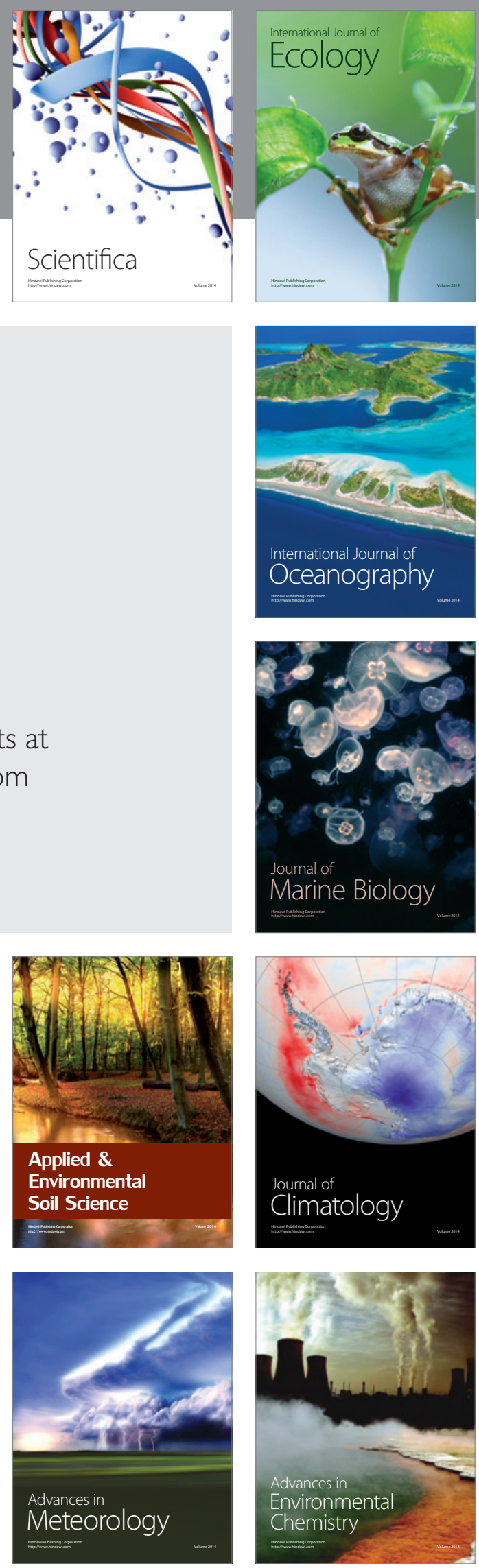